\title{
NEW SURVEY EVIDENCE ON THE PRICING BEHAVIOUR OF LUXEMBOURG FIRMS
}

by Patrick Lünnemann and Thomas Y. Mathä 
EUROPEAN CENTRAL BANK

\section{WORKING PAPER SERIES}

NO 617 / MAY 2006

\section{NEW SURVEY EVIDENCE ON THE PRICING BEHAVIOUR OF LUXEMBOURG FIRMS '}

by Patrick Lünnemann ${ }^{2}$

and Thomas Y. Mathä ${ }^{2}$

EUROSYSTEM INFLATION

PERSISTENCE NETWORK

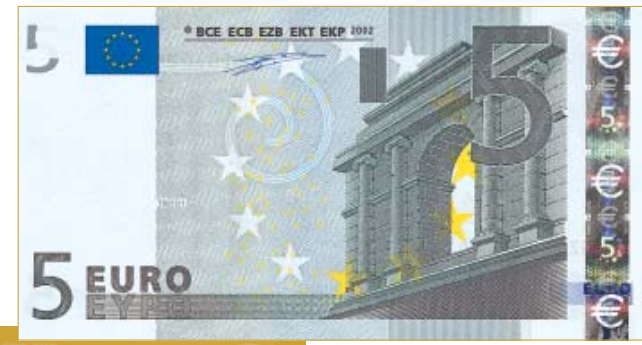

In 2006 all ECB

publications

will feature

a motif taken

from the

$€ 5$ banknote.

This paper can be downloaded without charge from http://www.ecb.int or from the Social Science Research Network electronic library at http://ssrn.com/abstract_id $=898129$

I This paper is part of the Eurosystem Inflation Persistence Network. We would like to thank Nico Weydert from STATEC for granting us access to the firm register and for sampling the firms surveyed, Martine Druant and Bettina Landau for their critical review of the questionnaire Olivier Marty, Guy Premont and Ladislav Wintr for assistance in data processing as well as Claudia Kwapil, other IPN members and an anonymous referee for their constructive help and criticism received. The views expressed in this paper are personal views of the authors and do not necessarily reflect those of the Banque centrale du Luxembourg or the Eurosystem. 


\section{The Eurosystem Inflation Persistence Network}

This paper reflects research conducted within the Inflation Persistence Network (IPN), a team of Eurosystem economists undertaking joint research on inflation persistence in the euro area and in its member countries. The research of the IPN combines theoretical and empirical analyses using three data sources: individual consumer and producer prices; surveys on firms' price-setting practices; aggregated sectoral, national and area-wide price indices. Patterns, causes and policy implications of inflation persistence are addressed.

Since June 2005 the IPN is chaired by Frank Smets; Stephen Cecchetti (Brandeis University), Jordi Galí (CREI, Universitat Pompeu Fabra) and Andrew Levin (Board of Governors of the Federal Reserve System) act as external consultants and Gonzalo Camba-Méndez as Secretary.

The refereeing process is co-ordinated by a team composed of Günter Coenen (Chairman), Stephen Cecchetti, Silvia Fabiani, Jordi Galí, Andrew Levin, and Gonzalo Camba-Méndez. The paper is released in order to make the results of IPN research generally available, in preliminary form, to encourage comments and suggestions prior to final publication. The views expressed in the paper are the author's own and do not necessarily reflect those of the Eurosystem.

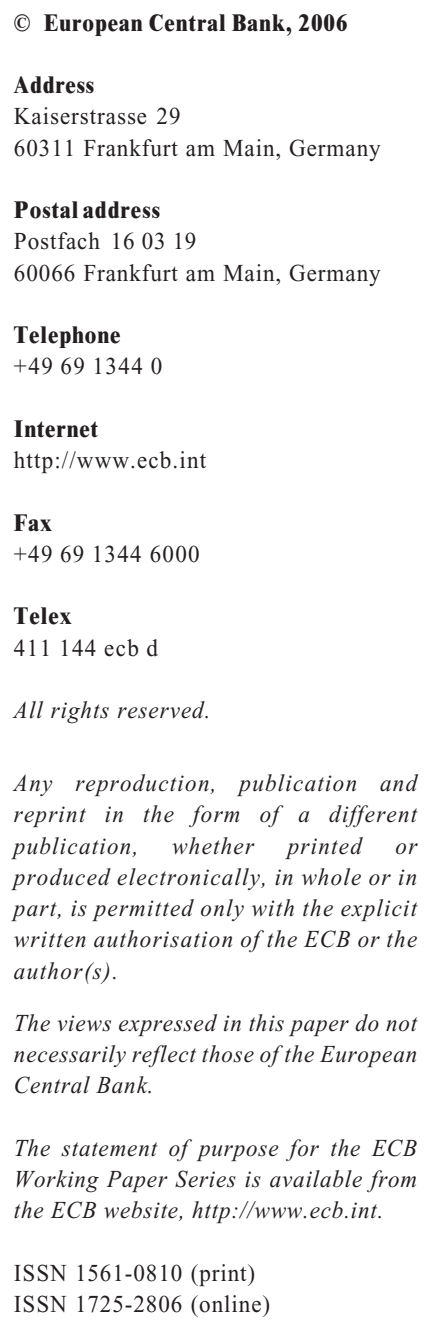

The views expressed in this paper do not necessarily reflect those of the European Central Bank. 


\section{CONTENTS}

Abstract

Non-technical summary

1. Introduction

2. Survey design

2.1 The sample

2.2 The questionnaire

3. Main market characteristics

3.1 Location of main market |

3.2 Client structure 12

3.3 The competitive environment 12

4. Price setting behaviour $\quad 16$

4.1 Who sets the price? $\quad 16$

4.2 Price review stage 16

4.3 Price setting stage 19

5. What theories can explain price stickiness? 23

5.1 Theories explaining price stickiness 23

5.2 Main results 26

6. Determinants of price changes 30

6.1 Driving factors of price changes 30

6.2 Speed of price adjustments 32

7. Conclusions 34

References 35

Appendix 37

European Central Bank Working Paper Series 42 


\section{Abstract:}

This paper analyses the pricing behaviour of Luxembourg firms based on survey evidence. Luxembourg firms typically have low market share, many competitors and longstanding customer relationships. Price discrimination is frequently applied. A majority of firms use price review rules that include elements of state dependency. The median firm reviews and changes prices twice a year. The results suggest an almost equal share of firms applying forwardlooking, backward-looking and rules of thumb behaviour. The adjustment speed is faster when cost goes up and demand goes down than in the opposite cases. The most relevant theories explaining price rigidity are implicit contracts, cost-based pricing and explicit contracts. Increases in labour and other costs are the most important factors leading to price increases; for price reductions it is price reductions by competitors followed by declining labour costs.

Keywords: Survey data, price setting, price rigidity, adjustment speed

JEL Codes: C21, C22, C14 


\section{Non-technical summary}

This paper reports the findings from a survey on the price setting behaviour of Luxembourg firms. In the second half of 2004, 1,133 Luxembourg firms from the construction, industry and services sector were contacted. Of these, 367 firms participated in the survey, resulting in an overall response rate of approximately $32 \%$. Firms were requested to disclose key characteristics of their market environment as well as main elements of their price setting practices and to disclose the obstacles to faster price adjustment.

The results show that $87 \%$ of the turnover is generated in Luxembourg whereas less than $1 \%$ of turnover is generated outside the euro area. As expected, foreign markets are more important for industrial firms. In general, Luxembourg firms have low market share, face a relatively large number of competitors and typically maintain longstanding customer relationships. Small market shares are particularly frequent for services firms, but relatively infrequent for industrial firms. The share of firms relying primarily on long-term customers is about $76 \%$.

In assessing the relevance of different factors for their competitiveness, firms assigned strongest recognition to the quality of their product. The price of the products and/or services ranks second, while the degree of product differentiation and after sales customer service received below average recognition.

With regard to price setting practices, almost $80 \%$ of firms set prices autonomously. The results suggest an almost uniform distribution for the share of backward-looking firms, forwardlooking firms and firms applying rules of thumb.

In addition, about $20 \%$ of firms review prices in regular intervals ("time-dependence"), whereas $48 \%$ of all firms do so in response to specific events ("state-dependence"). $22 \%$ of firms generally review at specific intervals, but also in response to specific shocks. Hence about $70 \%$ of firms surveyed include some elements of state-dependent rules when reviewing their prices. The median frequency of price reviews is twice per year.

With regard to firms' actual price setting policies, $65 \%$ of firms indicated to apply some sort of price discrimination. The results suggest an even spread between the two allowed options of price discrimination; either setting prices as a function of the quantity sold, but according to a uniform price list, or setting prices on a case-by-case basis. With respect to price discrimination $69 \%$ of firms serving foreign markets charge identical prices, whereas $4 \%$ apply identical prices across euro area countries.

With regard to the frequency of price changes, the median firm changes its price twice per year. The frequency of price changes varies considerably across sectors and firm size classes. Firms in the construction sector and trade sector change price more often than firms in industry or in the services sector.

Comparing the factors of importance for price increases with those of importance for price reductions reveals marked differences. Overall, increases in labour costs are the most important factor for price increases, followed by increases in other costs and wage indexation. In contrast, strengthening demand and higher prices by competitors receive the smallest average recognition for price increases. The most important factors for price reductions are price reductions by competitors followed by declining wage costs, while declining capital costs and productivity 
increases receive the smallest average recognition. For price increases, the average recognition exceeds those for price reductions for all factors considered in the survey except for the price of the competitors and demand fluctuations.

The speed of price adjustment depends on the type and the direction of the shock. Three main results emerge: First, firms seem to raise prices relatively soon in response to an increase in production costs. Approximately 50\% of firms adjust their main product's price within a single month. Second, firms seem to adjust prices much less rapidly in response to an increase in demand with almost every second firm not changing their price at all. Third, whereas the speed of price adjustment in response to rising costs is substantially different from that following a strengthening of demand, the speed of adjustment is much less asymmetric in the case of declining costs and demand.

Implicit contracts are considered the most important obstacle to price adjustment. The theory of constant marginal costs comes second, while explicit contracts rank third. Three other theories of price stickiness receiving substantial support from Luxembourg firms are procyclical elasticity, thick markets (demand side) and liquidity constraints. 


\section{Introduction}

This paper reports the findings of a survey on the price setting behaviour of Luxembourg firms. ${ }^{1}$ Surveys provide a means to help improving our understanding of the sources and the characteristics of existing frictions in the price adjustment mechanism as well as the monetary transmission process in more general, which cannot be analysed by solely relying on data from individual price records. In the second half of 2004, more than 1,000 Luxembourg firms from the construction, industry, services and trade (including retail) sectors were contacted. Firms were requested to disclose key characteristics of their market environment as well as main elements of their price setting practices. Among the price setting practices, the questionnaire focuses on the use made of time-dependent and state-dependent price setting, the role of forward-looking and backward-looking behaviour, the speed of adjustment in response to both demand and cost shocks as well as the determinants of price increases and price reductions. Finally, the survey aimed at identifying the obstacles to faster price adjustment.

The results reported in this paper show that, in general, Luxembourg firms have low market share, face a relatively large number of competitors and maintain longstanding customer relationships. Price discrimination is frequently applied and turnover reacts quite sensitively to price changes. In reviewing prices, a larger share of firms make use of state-dependent than time-dependent rules. The median price review frequency and the median price change frequency are twice per year. Industrial and trade firms are more forward-looking than construction and services firms. Prices adjust relatively fast to increasing costs and weaker demand. The most relevant explanations for delayed price adjustment are implicit contracts, constant marginal costs and explicit contracts. Increases in labour costs (including those due to wage indexation) and other costs are the most important factors leading to price increases; the most important driving factors for price reductions are price reductions by competitors, followed by reductions in labour costs.

Section 2 discusses the survey design and the sample selection. Section 3 discusses the main market characteristics, in which Luxembourg firms operate. Section 4 presents key characteristics of the pricing behaviour both at the price review and at the price setting stage.

\footnotetext{
This paper forms part of a wider research project, the Eurosystem Inflation Persistence Network (IPN), within which 8 national central banks have undertaken similar surveys. Detailed results for individual countries are provided by Kwapil et al. (2005) for Austria, Aucremanne \& Druant (2005) for Belgium, Loupias \& Ricart (2004) for France, Stahl (2005) for Germany, Fabiani et al. (2004) for Italy, Hoeberichts \& Stokman (2006) for the Netherlands, Martins (2005) for Portugal and Álvarez \& Hernando (2005) for Spain. For a cross-country comparison of main findings, see Fabiani et al. (2005).
} 
Section 5 discusses the obstacles to price adjustment. Section 6 analyses the determinants of price changes and the adjustment speed, while section 7 concludes.

\section{Survey Design}

\subsection{The sample}

In total, 1.133 companies were contacted by mail encompassing the sectors of trade, services (other than trade), industry and construction. The survey was based on a stratified sample drawn from the national statistical institute's (STATEC) economy wide firm register as at March 2004. ${ }^{2}$ The sample is stratified according to firm size (measured by the number of employees) and the sector of activity.

A full representation of the overall firm structure was impossible due to operational constraints with respect to the number of firms to be contacted. Furthermore, due to the relatively small number of companies in Luxembourg, there are only few firms in some size and activity strata of the total firm population. In order to obtain information across a relatively wide range of size and sector strata and at the same time having a minimum number of replies for each of these strata, specific sampling weights were used. Due to the above named reasons this stratification does not span across all size-sector combinations. In general, sectors firms of which were not expected to set prices autonomously, were not considered (e.g. agriculture, hunting and forestry, health, public administration and defence; compulsory social security). Furthermore, we exclude the sector of financial intermediation as well as companies with fewer than 5 employees. Within each of the strata considered, firms were chosen by means of random drawing. See Figure 1 for more details on the sample structure.

Out of the 1.133 firms contacted, 367 firms participated in the survey, resulting in an overall response rate of approximately $32 \%$, which is relatively low when compared to other recent firm surveys on pricing policy. ${ }^{3}$ Contrary to most of the recent firm surveys on price setting in euro area countries, though, this survey was not attached to already existing surveys (such as business cycle surveys) directed to a sample of firms that had revealed a sound willingness to participate in surveys in the past. As illustrated in Figure 1 the response rate varies substantially across strata, in particular along the size class dimension. $40 \%$ of large firms participated in the survey. The corresponding share for small firms is below $25 \%$. The maximum response rate is

\footnotetext{
The sampling was undertaken by the national statistical institute STATEC. See for example the appendix A provided in Fabiani et al. 2005.
} 
obtained for large industrial firms $(50 \%)$, while the minimum is recorded for small construction firms $(19 \%)$. With the exception of trade firms, the response rate increases with firm size.

Figure 1: Luxembourg firm structure, in percentages

\section{Total population}

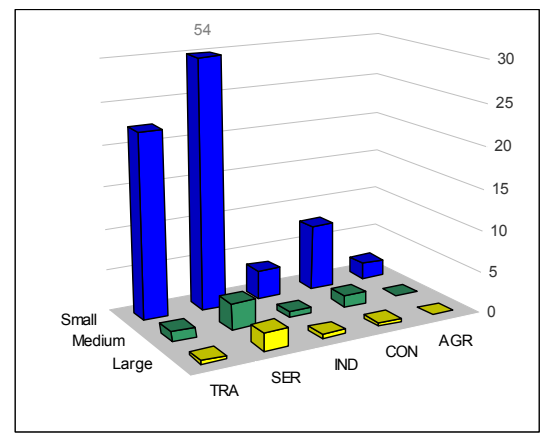

Firms contacted

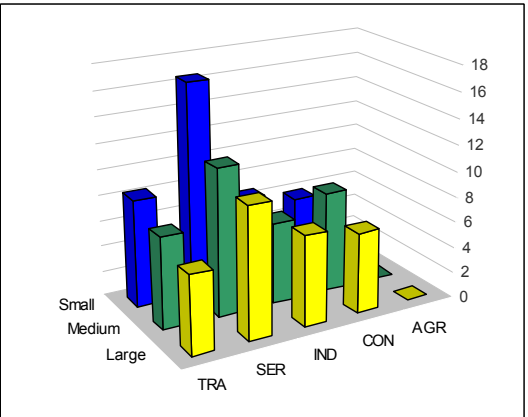

Replies

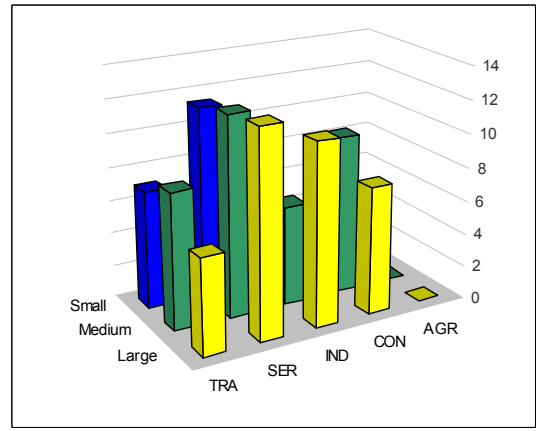

Figure 1 above suggests the presence of a sample bias. Both the composition of firms contacted as well as the structure of firms participating in the survey are not perfectly representative of the firm structure in Luxembourg, a property often reported in firm surveys. ${ }^{4}$ In particular, and apart from the size classes and/or the sectors ignored in our survey, smaller size companies are underrepresented whereas firms in sectors construction, industry and services other than trade tend to be overrepresented. In order to adjust for biases arising from non-representative sampling, the replies are post-stratified with respect to both economic activity and size class. ${ }^{5}$

See also Kwapil et al. (2005) on this point.

Numerical differences to the results provided Fabiani et al. (2005) are mainly due to a different weighting scheme adopted. 


\subsection{The questionnaire}

The survey, carried out by the Banque centrale du Luxembourg in August 2004, was designed in close correspondence to those used by Blinder et al. (1998), Hall et al. (2000), Apel et al. (2005) and those developed together in the IPN. ${ }^{6}$ The 5-page questionnaire is provided in Annex 1. In order to achieve best-possible return rates, questionnaires in both French and German were attached to a letter signed by a board member of the Banque centrale du Luxembourg, emphasising the importance of this survey. In addition, questions were designed such as to reduce the administrative burden faced by the respondents, for example by primarily requesting disclosure of qualitative information. In addition, respondents were most often offered a selection of pre-defined answers (such as a 4-point scale ranging from "unimportant" (1), "minor importance" (2), "important" (3) to "very important" (4)). To the extent possible, firms were offered a choice of ranges (e.g. on the market share). Only in few cases, firms were asked to provide quantitative information (e.g. on turnover). Whereas Blinder et al. (1998) surveyed a sample of 200 U.S. firms in face-to-face interviews, in our survey, firms were asked to respond by mail (a free-of-charge return envelope was enclosed). ${ }^{7}$ They were given telephone and email contacts for assistance.

The questionnaire is organised in three main parts. Part I collects general information about the participating firm (such as the number of employees) as well as about the market the firm operates in (such as the number of competitors). Part II focuses on the pricing setting behaviour of Luxembourg firms. As firms generally supply multiple products and serve multiple markets, for which the price setting practices may differ, firms were requested to base their answers exclusively on the domestic market of their main product. The aim of this part is to explore whether firms are forward- and/or backward-looking price setters, to assess the importance of time-dependent and/or state-dependent rules and to investigate the frequency of price changes and price reviews. Moreover, the section aims to identify the main factors for price reductions and price increases, and to find out the speed at which prices adjust to demand and cost shocks (both negative and positive). Lastly, section II assesses the importance of 15 theories of price stickiness. Part III captures elements of firms' pricing behaviour in foreign markets. This section concentrates on the use of price discrimination across export markets, the reasons for price discrimination and the degree of competition in foreign markets.

\footnotetext{
See for example Álvarez \& Hernando (2005), Aucremanne \& Druant (2005) and Martins (2005). Firms that did not reply to the initial mail were reminded to do so by October.
} 


\section{Main market characteristics}

In the following, we distinguish between four different sectors, namely construction $(C O N)$, industry (IND), trade (TRA) and services (SER). We further distinguish three firm size classes, namely small firms (S) with 25 employees or less, medium-sized firms $(M)$ with 26-75 employees and large firms $(L)$ with more than 75 employees. $^{8}$

\subsection{Location of main market}

The questionnaire contains two questions with regard to the geographical aspects of firms business. Question 2 asks what share of total turnover is generated in Luxembourg as well as on foreign markets, while Question 6 asks what country represents the most important market for the firm's main product. The results are given in Table 1. The predominant share of respondents indicated that the main market is Luxembourg. On average, $87 \%$ of the turnover is generated in Luxembourg. Almost the entire remainder is generated in the euro area, and less than $1 \%$ of turnover is generated outside the euro area. As expected, foreign markets are more important for industrial firms. For these firms, $67 \%$ of their turnover is generated abroad.

Table 1: Market Environment of Luxembourg Firms

\begin{tabular}{|c|c|c|c|c|c|c|c|c|}
\hline Question & Constr. & Industry & Services & Trade & Small & Medium & Large & All \\
\hline Share of total turnover in LU & 94 & 67 & 84 & 86 & 88 & 80 & 77 & 87 \\
\hline $\begin{array}{l}\text { Share of firms for which LU is main } \\
\text { market }\end{array}$ & 100 & 66 & 77 & 85 & 88 & 81 & 78 & 87 \\
\hline $\begin{array}{l}\text { Share of firms with mainly long-term } \\
\text { customer relationship }\end{array}$ & 64 & 91 & 77 & 85 & 74 & 88 & 90 & 76 \\
\hline $\begin{array}{l}\text { Share of firms with more than } 10 \\
\text { competitors on LU market }\end{array}$ & 72 & 32 & 61 & 61 & 64 & 49 & 46 & 61 \\
\hline $\begin{array}{l}\text { Share of firms with market share } \\
\text { below } 5 \%\end{array}$ & 53 & 34 & 65 & 47 & 55 & 35 & 26 & 51 \\
\hline $\begin{array}{l}\text { Share of firms that would increase } \\
\text { price by }>=5 \% \text { in absence of a direct } \\
\text { competitor in LU }\end{array}$ & 64 & 23 & 42 & 54 & 51 & 49 & 49 & 51 \\
\hline \multicolumn{9}{|c|}{ Question 2: $\quad$ What share of total turnover is generated in Luxembourg and outside Luxembourg? } \\
\hline \multirow{3}{*}{\multicolumn{9}{|c|}{$\begin{array}{l}\text { What share of total turnover is generated in Luxembourg and outside Luxembourg? } \\
\text { Which country reflects in terms of the turnover of your main product the most important market? } \\
\text { Do you generate the largest share of your turnover with long-term or short-term customers? } \\
\text { How many competitors (national and international) do you encounter for your main product on the } \\
\text { Luxembourg market? }\end{array}$}} \\
\hline & & & & & & & & \\
\hline & & & & & & & & \\
\hline \multicolumn{9}{|c|}{ How large is the market share of your main product on the Luxembourg market? (in percent) } \\
\hline 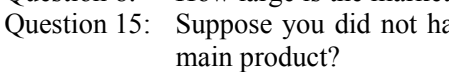 & \multicolumn{8}{|c|}{ Suppose you did not have any direct competitors. What would be the effect for the price of your } \\
\hline
\end{tabular}

For $87 \%$ of all firms, Luxembourg is also the most important market for their main product. With the exception of large industrial firms, Luxembourg is the main market for the main product irrespective of the size class or field of activity. For industrial firms, the fraction of

8 Note that in defining the sample we ignored firms with 5 employees or less (see section 2.1). 
firms serving Luxembourg as their main market for the main product declines as the firm size increases. The high importance of the foreign market in the industrial sector reflects that industrial products are essentially tradables, while construction and services are hardly so. Other factors are economies of scale and the small size of the domestic market.

\subsection{Client structure}

Firms were requested to characterise their main clientele as long-term customers (relationship with customers lasting more than one year) or alternatively as short-term customers (relationship with customers lasting one year or less) (Question 9). The survey reveals that 76\% of Luxembourg firms generate the largest share of turnover with long-term customers (see Table 1). For all size class and sector combinations considered, the share of firms maintaining primarily long-term customer relationships exceeds the share of firms primarily serving shortterm customers. The role of long-term customer relationships is particularly important for industrial firms (share of firms generating the largest share of turnover with long-term customers exceeding 90\%), but less so for construction firms (corresponding share 64\%). Overall, the role of long-term customers as the main client group increases with firm size. Whereas the share of firms generating the largest share of turnover with long-term customers is $74 \%$ for small firms, the corresponding share for large firms is $90 \%$.

\subsection{The competitive environment}

Competition is a key element for understanding the flexibility of prices. ${ }^{9}$ In theory, we would expect a negative relationship between competition and price rigidity (e.g. Rotemberg \& Saloner, 1987; Dornbusch, 1987). Empirically, Carlton (1986) has shown that price rigidity is strongly correlated with industry level concentration. Similarly, recent survey evidence for several euro area countries suggested that competitors' prices are an important factor for firms to reduce their prices (Fabiani et al., 2005). Finally, using micro price data from Luxembourg supermarkets, Lünnemann \& Mathä, (2005a) have shown that both the number of supermarkets competing with regard to a narrow product category and the market share are important determinants for the frequency of price change.

The survey incorporates several questions related to competition among firms. Firms were requested to indicate the number of competitors they face, their market share on the Luxembourg market, and how their prices would change if they did not face any competition.

9 For a survey on the link between competition and inflation see for example Asplund \& Friberg (1998). 


\subsubsection{Number of competitors}

First, firms were asked to characterise their main market by the number of competitors on the Luxembourg market (Question 7). Overall, about $60 \%$ percent of all firms face more than 10 competitors (see Table 1). The share of firms facing more than 10 competitors decreases with firm size ( $64 \%$ for small firms vs. $46 \%$ for large firms). $12 \%$ and $10 \%$ of firms estimate the number of their competitors to be between 1-4 and between 5-10, respectively (see Figure 2). Less than $2 \%$ of all firms say that they do not have any competitors. Approximately $15 \%$ of all firms responded not to know the number of competitors they face.

Figure 2: The number of competitors by economic activity and by firm size

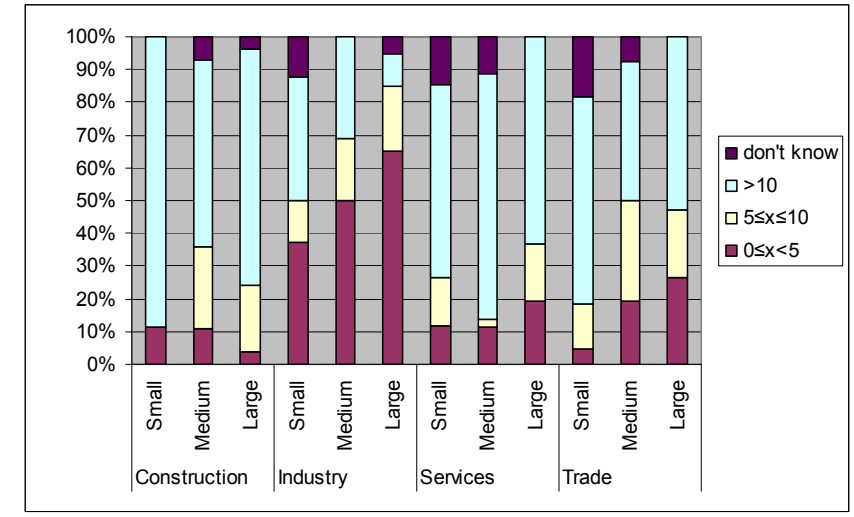

Question 7: How many competitors (national and international) do you encounter for your main product on the Luxembourg market?

Figure 2 displays some degree of variation across sectors of activity. Whereas in construction, more than $70 \%$ of firms face more than 10 competitors, their share is $32 \%$ in industry. In general, the number of competitors falls with increasing firm size class. In particular, this is the case for industrial firms, where $65 \%$ of large firms face less than 5 competitors. The share of firms not knowing the number of their competitors is particularly high for construction and trade firms (17\%).

\subsubsection{Market share}

In total, an absolute majority of firms estimate their market share to be less than or equal to $5 \%$ (Question 8) (see Figure 3). With a share of 65\% (34\%), these firms are relatively frequently (infrequently) encountered in services (industry). Still, for all four sectors considered, a market share of $5 \%$ or less has been the most frequently chosen response. Another $24 \%$ of all firms estimated their market share in the interval between $6 \%$ and $25 \%$. The share of firms considering that they capture $100 \%$ of the market is relatively high among trade firms (4\%), but 
zero for construction companies. The fraction of firms estimating their market share to be $100 \%$ is largest for large firms (3\%) and smallest for medium-sized firms $(0 \%)$.

Figure 3: Market share by firm size and economic activity

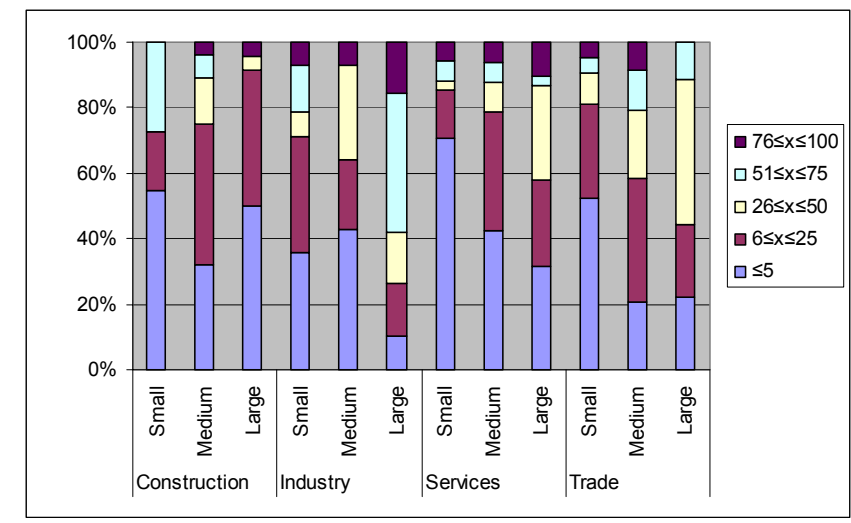

Question 8: How large is the market share of your main product on the Luxembourg market? (in percent)

\subsubsection{Competitiveness of companies}

Firms do not only compete in terms of prices, but also engage in non-price competition along a number of dimensions, such as the quality of their product, their customer service, the degree to which their product is differentiated from competitors' products, etc.. Firms were asked to assess the importance of these factors for their overall competitiveness according to a rank scale ranging from "unimportant" (1) to "very important" (4) (Question 11). Overall, in assessing their competitiveness, firms assigned strongest recognition to the quality of their product (see Table 2). This applies to all size and sector strata, except for large construction firms which consider quality only second to the price of the product. The product price ranks second place as a factor for competitiveness. The degree of product differentiation and after sales customer service received below average recognition. The delivery lag is considered the least important criterion in terms of competitiveness. Differences across criteria are, however, very small, as on average almost all criteria are considered important.

The variation in the importance assigned to the different factors for competitiveness across sectors and firm size classes is substantial. The degree of product differentiation receives strong support from services firms, but limited support from industrial firms. The latter, contrary to all other sectors considered, also assign strong recognition to delivery lags. Interestingly, customer service receives least recognition by services firms (almost midway between unimportant and important) but receives relatively strong recognition in the construction sector. 
Table 2: Criteria of competitiveness (rating on a 4-point scale)

\begin{tabular}{lcccccccc}
\hline Factor & Constr. & Industry & Services & Trade & Small & Medium & Large & All \\
\hline Quality of product & 3.7 & 3.8 & 3.9 & 3.8 & 3.8 & 3.7 & 3.7 & 3.8 \\
Price of product & 3.5 & 3.3 & 3.4 & 3.4 & 3.4 & 3.4 & 3.6 & 3.4 \\
Long-term relationship & 3.2 & 3.5 & 3.4 & 3.3 & 3.3 & 3.4 & 3.3 & 3.3 \\
Customer service & 3.4 & 3.1 & 2.6 & 3.2 & 3.1 & 3.1 & 2.8 & 3.1 \\
Product differentiation & 3.0 & 2.9 & 3.3 & 3.0 & 3.0 & 3.1 & 3.0 & 3.0 \\
Delivery lags & 2.9 & 3.3 & 2.8 & 2.9 & 2.9 & 3.1 & 3.2 & 2.9 \\
\hline Average & 3.3 & 3.3 & 3.2 & 3.2 & 3.3 & 3.3 & 3.3 & 3.3 \\
\hline \hline & Question 11: & The competitiveness of your company can depend on several factors: Please indicate the \\
& relevance of the factors listed below for the competitiveness of your company: (1) \\
& unimportant, (2) minor importance, (3) important and (4) very important
\end{tabular}

\subsubsection{On the impact of competitors on firms' prices}

Overall, approximately $50 \%$ of all firms expect their prices to rise by at least $5 \%$ in absence of a direct competitor (Question 15). Whereas more than $40 \%$ of all firms expect the price of their main product to increase by between $5 \%-10 \%$, approximately $10 \%$ of firms estimate the impact to be $\geq 10 \%$. More than $30 \%$ of firms expect the price of their main product not to change at all in the absence of an immediate competitor.

Figure 4: On the impact of direct competition on firms' prices

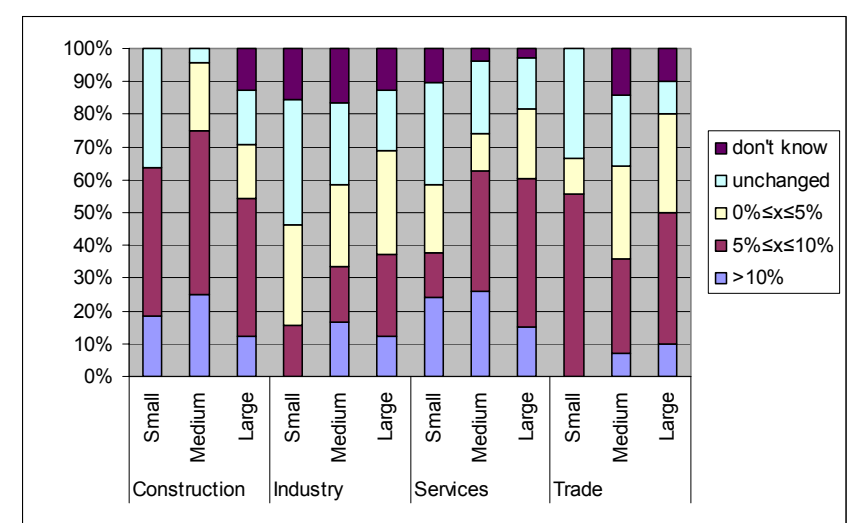

Question 15: Suppose you did not have any direct competitors. What would be the effect for the price of your main product?

Figure 4 above illustrates the substantial variation across firm size classes and sectors with respect to the expected impact of immediate competition on prices. The share of firms expecting a strong impact on their main product's price in the absence of an immediate competitor (i.e. $\geq 10 \%$ ), is relatively high for small and medium-sized construction and services firms. In contrast, a negligible share of firms in the trade sector reports a strong impact of competitors on 
the price of their main product ( $<10 \%$ across all size classes). Figure 4 further illustrates that small firms in particular deny that prices would differ in the absence of a direct competitor.

\section{Price setting behaviour}

\subsection{Who sets the price?}

$79 \%$ of firms set prices autonomously (Question 14). $8 \%$ of all firms report the price of their main product to be determined at the group level, whereas in $5 \%$ of all cases, a public institution determines the price. Another $8 \%$ of all firms state that their prices to be fixed by other institutions.

Figure 5: On the origin of price setting

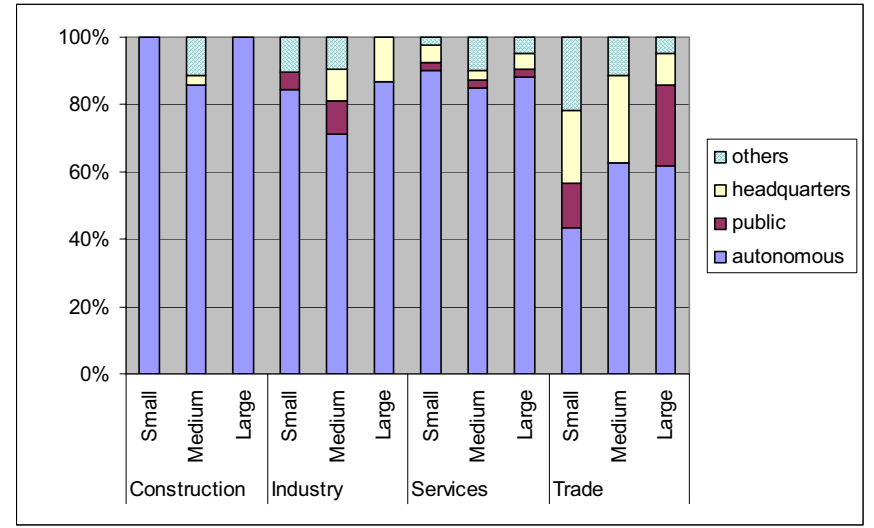

Question 14: Do you set the price of your product yourself or is the price determined elsewhere?

Across all firm size classes and all sectors considered, autonomous price setting is by far the most frequent response chosen (see Figure 5). Substantial differences prevail though: Whereas $99 \%$ of all construction firms are in a position to set prices autonomously, the same applies to only $46 \%$ of all trade firms. In contrast, the share of firms setting prices autonomously is by and large independent of the firm size. Interestingly, the fraction of firms whose price setting is subject to public administration is largest for large trade firms (almost 25\%).

\subsection{Price review stage}

\subsubsection{Time-versus state-dependent price reviewing rules}

$20 \%$ of firms review prices in regular intervals ("time-dependence" hereafter), whereas $48 \%$ of all firms do so in response to specific events ("state-dependence") (Question 16). 22\% of firms generally review at specific intervals, but also in response to specific shocks. Hence about $70 \%$ of firms surveyed include some elements of state-dependent rules when reviewing their prices, 
thus stressing the importance of being able to react swiftly to changes in firms' relevant economic conditions. Table 3 illustrates that for all sector and size combinations, purely statedependent price reviewing rules are more frequently used than purely time-dependent rules. ${ }^{10}$ For selected sector-size combinations (small construction companies and medium-sized trade firms), the share of firms applying purely state-dependent price setting is 8 times as large as the fraction of firms using purely time-dependent pricing rules.

Concerning cross-sectoral differences, we note that purely time-dependent price reviews are particularly infrequent with construction firms (9\%) and services firms (15\%) but relatively frequent with trade firms (28\%). The use of purely state-dependent price review rules is particularly frequent in the construction and the industrial sector (both almost 60\%). Overall, the share of firms using purely state-dependent rules is a decreasing function of firm size. At the sector level, though, no stable pattern with respect to the firm size can be discerned.

Table 3: Firms' price reviewing behaviour

\begin{tabular}{|c|c|c|c|c|c|c|c|}
\hline & \multicolumn{4}{|c|}{ Time- vs. state-dependency } & \multicolumn{3}{|c|}{ Backward vs. forward looking } \\
\hline & Time & State & Both & $\begin{array}{l}\text { Don't } \\
\text { know }\end{array}$ & $\begin{array}{c}\text { Rules of } \\
\text { thumb }\end{array}$ & Backward & Forward \\
\hline Construction & 9 & 59 & 18 & 15 & 32 & 48 & 20 \\
\hline Industry & 20 & 59 & 19 & 2 & 41 & 19 & 40 \\
\hline Services & 15 & 50 & 27 & 8 & 35 & 35 & 30 \\
\hline Trade & 28 & 40 & 22 & 9 & 29 & 30 & 42 \\
\hline Small & 21 & 49 & 19 & 10 & 33 & 36 & 31 \\
\hline Medium & 16 & 45 & 35 & 5 & 24 & 20 & 55 \\
\hline Large & 17 & 42 & 37 & 4 & 22 & 26 & 52 \\
\hline All & 20 & 48 & 22 & 10 & 32 & 34 & 34 \\
\hline Question 16: & $\begin{array}{l}\text { Companies oft } \\
\text { review the actu } \\
\text { dependent), ge } \\
\text { as reaction to a } \\
\text { as reaction to a }\end{array}$ & $\begin{array}{l}\text { eview } \\
\text { harge } \\
y \text { in re } \\
\text { tantial } \\
\text { tantial }\end{array}$ & $\begin{array}{l}\text { price } \\
\text { s pric } \\
\text { inter } \\
\text { ge in } \\
\text { ge in }\end{array}$ & $\begin{array}{l}\text { ithout } \\
\text { your n } \\
\text { but al } \\
\text { ) (bot } \\
\text { (state }\end{array}$ & $\begin{array}{l}\text { sarily cl } \\
\text { roduct in } \\
\text { response } \\
\text { response } \\
\text { endent)? }\end{array}$ & $\begin{array}{l}\text { anging then } \\
\text { regular inter } \\
\text { to specific } \\
\text { to specific }\end{array}$ & $\begin{array}{l}\text { A. Do you } \\
\text { vals (time } \\
\text { events (e.g } \\
\text { events (e.g }\end{array}$ \\
\hline Question 18: & How did you 1 & witl & ast pr & iew & or main pr & oduct? & \\
\hline
\end{tabular}

The use of both time-and state-dependent pricing rules reveals marked differences across size classes and sectors. Hybrid rules are particularly prominent with services firms (27\%), but particularly infrequent with construction firms (18\%). Contrary to purely time- and statedependent rules, the differences in the use of hybrid rules are even more pronounced with respect to firm size. Whereas hybrid rules are relatively infrequently used by small firms (19\%), more than $1 / 3$ of all medium-sized and large firms prefer a combination of state- and timedependent pricing rules. Approximately $10 \%$ of all firms - and mostly small firms - were

10 Except for large industrial firms, where purely time-dependent rules were as frequently applied as purely statedependent behaviour. 
unable to characterise their price setting behaviour by one of the three options provided in the questionnaire.

\subsubsection{Backward and forward looking behaviour or rules of thumb}

Referring to their most recent decision to change prices, Question 18 requested firms to disclose whether the price review took into consideration a vast amount of information exclusively referring to present and future ("forward-looking") developments, or to past and present ("backward-looking") developments in the firm's business conditions or, alternatively, whether they used a pre-defined rule ("rule of thumb behaviour"). Overall, our results suggest an almost uniform distribution for the share of backward-looking firms (34\%), forward-looking firms (34\%) and firms applying rules of thumb (32\%) (see Table 3). The share of firms using backward-looking price reviewing behaviour differs substantially across firm size classes and sectors. While almost every second firm in the construction sector characterises its price review as backward-looking, this is only the case for about every fifth industrial firm. The largest shares of forward-looking firms are found in trade (42\%) and industry (40\%), while construction firms $(20 \%)$ are the least forward-looking. In general, small firms tend to use backward-looking practices more often than medium-sized and large firms. The industrial and construction sector show a clear pattern of increased forward-looking behaviour as the firm size class increases. With a share of $41 \%$, industrial firms frequently apply rules of thumb. However, this response is also the most often chosen option by large services firms, while it is the least frequently chosen option among large construction firms, medium-sized industrial firms and large trade firms. Rule of thumb behaviour decreases as the firm size class increases in the construction and trade sector.

\subsubsection{Frequency of price reviews}

Firms responding that they review prices in regular intervals were subsequently asked how often they review their prices (see Question 17). The median over all firms is two price reviews a year. $76 \%$ of firms review their prices at quarterly frequency or less often, while the remaining $24 \%$ of firms review prices at monthly frequency or higher. Overall, the share of firms reviewing prices more than once per year is about $60 \%$. The corresponding share for construction, industrial and services firms is each roughly $2 / 3$, while only $52 \%$ of trade firms review their prices more than once a year (see Table 4). The modal frequency of price reviews is annual for trade firms, semi-annual for services and industry and quarterly for construction. The median price review frequency is 2 times a year for construction, industrial and services firms while it is 4 times per year in the trade sector. For those time-dependent firms reviewing their 
prices annually, a stark seasonal pattern emerges; more than $50 \%$ of firms review prices in January.

Within the trade sector, a clear bimodal distribution is discernible - whereas approximately $46 \%$ of all trade firms prefer to review prices weekly, another $47 \%$ review prices at annual frequency only. Approximately $1 \%$ of all firms review prices at daily frequency, mostly medium-sized construction (29\%) and medium-sized trade firms (25\%). Daily price reviews do appear neither in small firms nor in industrial firms.

Table 4: Price review frequency, per sector and size class

\begin{tabular}{lcccccccc}
\hline & Constr. & Industry & Services & Trade & Small & Medium & Large & All \\
\hline Daily & 1 & 0 & 1 & 2 & 0 & 13 & 12 & 1 \\
Weekly & 1 & 1 & 0 & 46 & 20 & 1 & 17 & 19 \\
Monthly & 1 & 17 & 8 & 1 & 3 & 8 & 4 & 3 \\
Quarterly & 33 & 23 & 18 & 1 & 17 & 20 & 15 & 17 \\
Half-yearly & 32 & 27 & 40 & 2 & 20 & 27 & 18 & 21 \\
Yearly & 32 & 12 & 32 & 47 & 38 & 24 & 28 & 36 \\
Less than yearly & 0 & 21 & 1 & 0 & 2 & 7 & 6 & 2 \\
\hline Total & 100 & 100 & 100 & 100 & 100 & 100 & 100 & 100 \\
\hline Median & 2 & 2 & 2 & 4 & 2 & 2 & 2 & 2 \\
\hline \hline Question & $17:$ & You & review & prices without & necessarily changing & them (this does not \\
& presuppose that prices change). How often do you normally review the price \\
& (please tick on answer only)?
\end{tabular}

\subsection{Price setting stage}

\subsubsection{Price discrimination}

Question 12 asked whether Luxembourg firms charge identical prices or whether they price discriminate. The survey distinguished between two forms of price discrimination, namely setting prices as a function of the quantity sold, but according to a uniform price list, or alternatively setting prices on a case-by-case basis. Our results suggest an almost even split between all three options. The share of firms charging identical prices is approximately $35 \%$, whereas $65 \%$ of firms apply some sort of price discrimination.

In contrast to the overall results, construction and trade firms reveal strong preferences for a single option (with more than a 30-percentage point difference between the most frequently and the most infrequently chosen option). The share of firms charging identical prices is particularly high for services and trade firms (both almost 50\%) and lowest for construction firms (15\%). Whereas for services and construction firms the share of firms charging identical prices shrinks with increasing firm size, this is not the case for industrial firms and trade firms. Overall, charging an identical price is the modal outcome for all sectors except for construction. 
Figure 6: Price discrimination per sector and size class

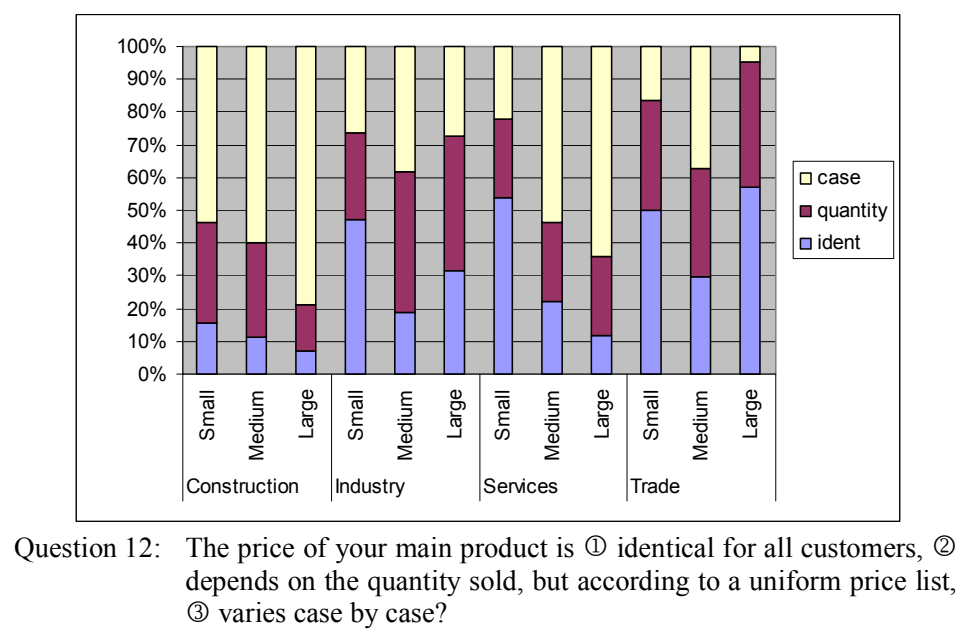

Approximately $30 \%$ of all firms price discriminate according to the quantity sold, but according to a uniform price list. Overall, the share of firms price discriminating according to a uniform price list is relatively stable across size classes (between 30\% and 33\%) and across sectors (from $24 \%$ for services to $34 \%$ for trade firms). This option is the modal response for mediumsized and large industrial firms only. Another $35 \%$ of all firms trade their main product at prices varying case by case. Interestingly, we find substantial variation in the share of firms preferring the case-by-case setting (from only $17 \%$ in trade to approximately $55 \%$ in construction).

\subsubsection{Pricing-to-market (PTM)}

As Luxembourg exhibits a very small domestic market, firms start operating internationally at a very early stage in order to grow. Firms serving foreign markets were asked whether they price to market and, if so, were requested to assess the importance of 7 potentially relevant factors (e.g. variations in the exchange rate, tax system, transport costs) according to a rank scale ranging from "unimportant" (1) to "very important" (4). 69\% of firms apply identical prices across all markets, a figure fairly high compared to other euro area countries (see for example Fabiani et al. 2005). 4\% of firms responded that prices are equal across euro area countries, while $27 \%$ of firms responded that prices differ across countries (see Table 5). The relatively high figure for identical prices may however relate to the fact that foreign activities of many firms surveyed make up a small percentage of total sales only. If only a negligible amount of sales emanates from abroad, firms are likely to be unwilling bearing the cost of fully optimising their prices charged abroad. Implicitly, this is borne out in Table 5, where the share of price discrimination across markets increases with firm size class. 
Table 5: Pricing-to-market

\begin{tabular}{lcccccccc}
\hline Price setting across markets & \multicolumn{3}{c}{ Constr. Industry Services } & Trade & Small Medium Large & All \\
\hline Price is the same in all countries & 71 & 69 & 65 & 72 & 70 & 60 & 53 & 69 \\
Price is the same for euro area countries & 1 & 2 & 10 & 0 & 5 & 4 & 3 & 4 \\
Price is different across all countries & 28 & 28 & 24 & 28 & 25 & 36 & 44 & 27 \\
\hline Total & 100 & 100 & 100 & 100 & 100 & 100 & 100 & 100 \\
\hline \hline
\end{tabular}

Question 24: Companies may charge different prices on different markets: Which of the following statements is true for your company?

The most important reasons for price discrimination across nationally segmented markets are transportation costs and the price of the competitors, followed by the level of regulation, the tax system and structural market conditions (see Table 6). Exchange rate developments seem on the contrary only of minor importance for price discriminating behaviour, which is in line with the low turnover generated outside the euro area (1\%). As firms grow their activities span over more countries. Consistent with this interpretation, the importance of exchange rate variations increases with increasing firm size class.

Table 6: Relevance of factors for price discrimination across markets

\begin{tabular}{lcccccccc}
\hline Importance factors for PTM & Constr. & Industry & Services & Trade & Small & Medium & Large & All \\
\hline Transport cost & 3.0 & 3.5 & 2.9 & 3.1 & 3.0 & 3.7 & 3.5 & 3.1 \\
Price of competitors & 2.1 & 2.1 & 3.0 & 3.4 & 2.6 & 3.1 & 3.1 & 2.7 \\
Level of regulation & 2.0 & 3.0 & 2.5 & 2.2 & 2.4 & 1.6 & 2.7 & 2.4 \\
Tax system & 1.1 & 3.4 & 2.9 & 2.4 & 2.3 & 1.3 & 3.3 & 2.2 \\
Structural conditions & 1.1 & 2.5 & 2.5 & 2.9 & 1.9 & 3.6 & 3.2 & 2.1 \\
Cyclical demand changes & 1.1 & 2.1 & 3.3 & 2.4 & 1.9 & 2.9 & 2.9 & 2.1 \\
Variations in exchange rates & 1.0 & 2.4 & 1.0 & 1.8 & 1.2 & 1.2 & 2.1 & 1.2 \\
\hline \hline
\end{tabular}

Question 25: Please indicate to what extent the following factors are relevant for the pricing behaviour of a product (outside of Luxembourg). Please choose one of the following options for each of the factors: (1) unimportant, (2) minor importance, (3) important and (4) very important.

\subsubsection{Frequency of price changes}

Overall, the median firm changes its price 2 times per year. $28 \%$ of all firms change prices exactly once per year. The frequency of price changes varies considerably across sectors and firm size classes (see Table 7). Firms in the construction sector and trade sector change their price more often than firms in industry or services. In the latter two sectors, it is particularly apparent that only $13 \%$ and $16 \%$ of firms change their price more often than twice per year.

The median frequency of 2 price changes per year compared to the 1 price change per year reported by other euro area country studies may be partly related to the inclusion of the construction sector. Aucremanne \& Druant (2005) report that firms in the construction sector change prices more frequently than firms in other sectors. Similar to our results, Álvarez \& 
Hernando (2005) and Hoeberichts \& Stokman (2006) report for Spanish and Dutch firms that firms in the trade sector change prices more often than industrial firms.

Table 7: Price change frequency, per sector and size class

\begin{tabular}{lccccccccc}
\hline & Constr. & Industry & Services & Trade & Small & Medium & Large & All \\
\hline Daily & 16 & 0 & 3 & 2 & 7 & 8 & 6 & 7 \\
Weekly & 8 & 1 & 0 & 22 & 10 & 4 & 8 & 10 \\
Monthly & 8 & 7 & 3 & 5 & 6 & 7 & 6 & 6 \\
Quarterly & 9 & 5 & 9 & 14 & 10 & 9 & 9 & 10 \\
Half-yearly & 33 & 29 & 36 & 28 & 34 & 28 & 18 & 32 \\
Yearly & 17 & 41 & 37 & 28 & 26 & 32 & 45 & 28 \\
Less than yearly & 7 & 17 & 11 & 1 & 7 & 13 & 7 & 8 \\
\hline Total & 100 & 100 & 100 & 100 & 100 & 100 & 100 & 100 \\
\hline Median & 2 & 1 & 2 & 2 & 2 & 2 & 1 & 2 \\
\hline \hline
\end{tabular}

Question 23: At which interval do you change the price of your main product (please also consider possible discounts, but not end-of-season sales or similar) (please tick one answer only)?

Many reasons can be envisaged that explain the differences between firms' frequency to review and change prices. One possible explanation of why firms often review but rarely change prices could be that the costs of reviewing prices are limited whereas the costs of implementing price changes are relatively sizeable. At the same time, the frequency of price review may simply be a reflection of the frequency and/or magnitude of occurring shocks, as even very small review costs imply a very low price review frequency in an environment of rare or negligible shocks, even more so if the firm adopts a flexible or purely state-dependent price reviewing strategy. In contrast, a high price review frequency linked to very frequent price changes could either reflect low costs both at the review and the implementation stage or relatively high costs of changing price in a very volatile business environment with frequent and/or sizeable shocks to relative prices.

Figure 7 below compares the price change frequency to the price review frequency. Strikingly, almost $75 \%$ of firms apply identical frequencies to both price changes and price reviews. Among the remaining firms, almost $80 \%$ review their prices at quarterly frequency and change them twice or once a year or, alternatively, review their prices twice a year and change them once a year. Thus, the price change frequency rarely deviates from the price review frequency in a substantial manner. The most common review frequency/change frequency constellations are annual/annual (25\%) and semi-annual/semi-annual (16\%). More than $10 \%$ of firms both review and change their prices at daily frequency. 
Figure 7: Price review and price change frequencies compared

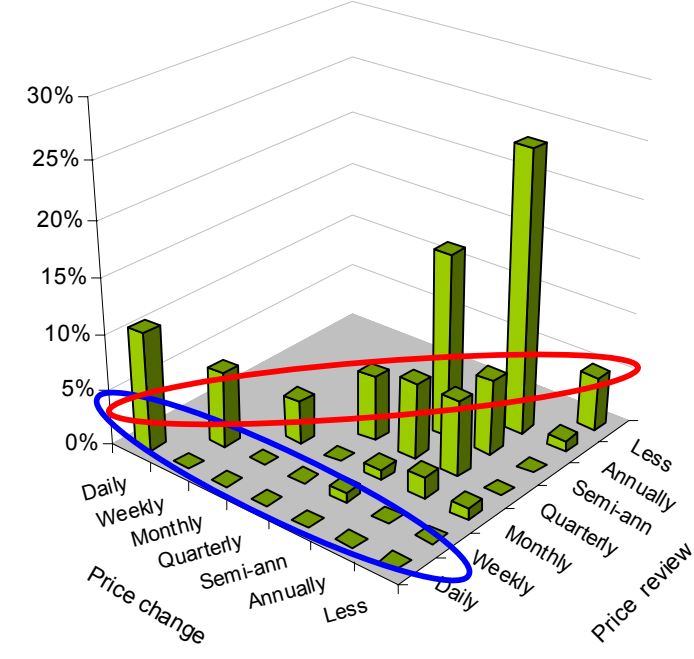

\section{What theories can explain price stickiness?}

As a key complement to the analysis of inflation persistence at the aggregate and the sectoral level as well as the analysis of consumer prices at the micro level, the survey essentially aimed at identifying the most important obstacles to faster price adjustment. In sum, the survey proposed 15 reasons for price stickiness, the choice of which owes much to the inventory of theories presented in the seminal work by Blinder et al. (1998). In Question 20, Firms were asked to assess the importance of each of these reasons according to a rank scale ranging from "unimportant" (1) to "very important" (4).

\subsection{Theories explaining price stickiness}

\section{Explicit nominal contracts}

The terms of written contracts between a firm and its customers specify fixed prices for finite periods of time. Modifications to explicit contractual terms would require undue renegotiations.

\section{Physical menu costs}

This theory has become a mainstay of New Keynesian theory and owes to the idea that firms might be reluctant to change prices in response to a supply or demand shock because of the costs of printing new price lists. In their purest form, menu costs may be considered independent of the size of the change, implying infrequent but sizeable price changes. Due to the absence of data on menu costs, empirical testing of this theory has proven difficult. 


\section{Cost of information gathering and processing}

Firms may prefer not to adjust prices instantly because gathering and processing information required by pricing policy decisions is costly and time consuming.

\section{Implicit contracts}

According to the invisible hand shake theory by Okun (1981), buyers and sellers who value long-term relationships may enter into implicit contracts under which, for example, sellers pledge not to exploit a tightening of market conditions by raising prices. Buyers, in turn, might agree not to insist on price reductions when markets turn down. ${ }^{11}$ Price changes are considered damaging customer relations.

\section{Coordination failure}

Depending on the market environment, firms may not change prices in fear of sparking off a price war. Lacking an effective coordination mechanism, firms may prefer to "wait and see" for others to change their prices and to follow suit. The risk of prices not moving in concert may add to price rigidity. Coordination failures can arise on the upward as well as on the downward side.

\section{Fixed costs / liquidity constraints}

During economic downturns, firms typically generate less cash flow. In an environment of large fixed costs, firms may prefer not to reduce prices in order to keep a sufficient amount of liquidity whereas a price reduction would lead to increased turnover not until after a substantial time lag.

\section{Constant marginal costs}

Constant marginal costs suggest that variable costs per unit of output are broadly constant over a wide range of production levels. In an environment of a flat marginal cost function, a profitmaximising firm has but small incentives to change prices with changes to demand. As pointed out by Blinder et al. (1998), if firms apply a constant mark up to marginal costs, a flat marginal cost function implies a fairly constant price over the business cycle.

\section{8. $\quad$ Thick markets - demand side}

This theory owes to the idea of changing market conditions over the business cycle. With respect to customer demand, it is suggested that the incentive of customers to compare prices is

11 However, economic theory is not conclusive on whether the handshake theory applies to nominal or real prices. 
an increasing function of the quantities demanded. Hence, customers are expected to react more sensitively to price changes during cyclical upswings than in downturns.

\section{Thick markets - supply side}

On the supply side, the firms' cost of reaching customers is smaller in economic upswings. In such an environment firms may prefer to keep their price at a relatively low level in spite of stronger economic activity.

\section{Countercyclical external financing constraints}

During economic downturns, firms may find it more difficult to obtain external financing. Firms with lack of access to bank loans or similar external finance may, therefore, prefer to keep prices at a high level.

\section{Procyclical elasticity of demand}

This theory is based on the assumption of procyclical marginal costs and countercyclical markups. There are many reasons for firms to employ countercyclical mark-ups, one of which suggesting that products attract customers with varying attachment to the firms' products, hence varying price elasticities of demand. For example, regular loyal customers have low price elasticities, whereas occasional or one-off customers have much higher price elasticities. Then, the customer mix varies with the business cycle: in a recession, firms lose their least loyal customers, thereby facing an increasingly inelastic demand curve. Correspondingly, during economic upturns, the elasticity of demand increases.

\section{Pricing threshold and attractive prices}

Firms may prefer to set prices attractively (say at $€ 4.99$ instead of $€ 5.01$ ), assuming that increasing prices beyond these thresholds incurs a fall in demand out of proportion to the price increase (i.e. very elastic demand curve at levels immediately above pricing thresholds). Pricing thresholds imply that prices are more sticky upwards than downwards (e.g. Lünnemann \& Mathä, 2005 on this point for CPI data). Given that consumers may be particularly responsive to pricing thresholds and given the frequent use made of attractive prices in retailing, we expect this theory to be particularly important in the retail sector.

\section{Temporary shocks}

Firms may prefer not to adjust prices immediately as they may expect their optimal price to change in the opposite direction soon afterwards. 


\section{Judging quality by price}

In an environment of imperfect information on product quality, the assumed correlation between price and quality may lead to a smaller frequency of price reductions. In particular, a firm contemplating a price cut might fear that customers might misinterpret the price reduction as a reduction in quality. As product quality is not observable, the phenomenon of judging by price is difficult to analyse empirically. As pointed out by Hall et al. (1996), quality signalling may be particularly relevant for luxury goods and niche markets.

\section{Adjustments other than price changes}

In the short run, rather than changing prices instantly, firms may prefer to respond to changes in market conditions by adjusting stock and/or by postponing the ultimate price/output adjustment through changed delivery times. This theory suggests that - ceteris paribus - the degree of price stickiness is stronger the lower the costs of varying inventories.

\subsection{Main results}

Evidence from former surveys undertaken in Sweden, UK and the U.S. suggests that the relative importance of the different theories of price stickiness may differ not only across countries, but also - within a given country - across sectors and by firm size.

Overall, in rank terms, the results indicate that Luxembourg companies consider implicit contracts the most important obstacle to faster price adjustment (see Figure 8). The theory of constant marginal costs comes second in our ranked table of theories. Explicit contracts rank third. Both explicit and implicit contracts as well as the theory of constant marginal costs have received strong recognition by firms in other countries as well (e.g. Fabiani et al., 2005). The three other theories of price stickiness receiving substantial recognition, across all sectors and firm size classes, from Luxembourg firms are procyclical elasticity, thick markets (demand side) and liquidity constraints. 
Table 8: Ranking of reasons for price rigidity (rating on a 4-point scale)

\begin{tabular}{l|c|cccccccc}
\hline Theory & Question & Constr. & Industry & Services & Trade & Small & Medium & Large & All \\
\hline Implicit contracts & $\mathbf{4}$ & $\mathbf{2}$ & $\mathbf{3}$ & $\mathbf{4}$ & $\mathbf{3}$ & $\mathbf{1}$ & $\mathbf{1}$ & $\mathbf{2}$ & $\mathbf{1}$ \\
Constant MC & 7 & $\mathbf{3}$ & $\mathbf{1}$ & $\mathbf{1}$ & $\mathbf{4}$ & $\mathbf{2}$ & $\mathbf{3}$ & $\mathbf{3}$ & $\mathbf{2}$ \\
Explicit contracts & $\mathbf{1}$ & $\mathbf{1}$ & $\mathbf{4}$ & 7 & 8 & 5 & $\mathbf{2}$ & $\mathbf{1}$ & $\mathbf{3}$ \\
Procycl. elasticity of demand & 11 & 6 & 5 & $\mathbf{3}$ & $\mathbf{2}$ & $\mathbf{4}$ & $\mathbf{4}$ & 5 & $\mathbf{4}$ \\
\hline Thick markets demand & 8 & $\mathbf{4}$ & 6 & 8 & $\mathbf{1}$ & $\mathbf{3}$ & 6 & 7 & 5 \\
Fix costs / liquidity constraints & 6 & 5 & $\mathbf{2}$ & 5 & 9 & 6 & 5 & $\mathbf{4}$ & 6 \\
Quality & 14 & 7 & 10 & $\mathbf{2}$ & 10 & 8 & 7 & 8 & 7 \\
Thick markets supply & 9 & 8 & 9 & 6 & 7 & 7 & 9 & 11 & 8 \\
Coordination failure & 5 & 12 & 7 & 9 & 6 & 9 & 8 & 6 & 9 \\
Threshold pricing & 12 & 15 & 15 & 14 & 5 & 10 & 15 & 13 & 10 \\
Temporary shock & 13 & 14 & 13 & 13 & 11 & 11 & 13 & 14 & 11 \\
Countercyclical finance & 10 & 10 & 11 & 11 & 13 & 12 & 11 & 10 & 12 \\
Menu cost & $\mathbf{2}$ & 11 & 12 & 10 & 14 & 13 & 12 & 9 & 13 \\
Non-price factors & 15 & 9 & 8 & 12 & 15 & 14 & 10 & 12 & 14 \\
Costly information & $\mathbf{3}$ & 13 & 14 & 15 & 12 & 15 & 14 & 15 & 15 \\
\hline \hline
\end{tabular}

Note: Ranked according to column "All".

Question 20: There are numerous reasons why prices are not or only slightly changed during a certain time interval. Please indicate to what extent each of the potential reasons listed below is relevant for your company. Please choose one of the following options for each of the factors: (1) unimportant, (2) minor importance, (3) important and (4) very important.

In contrast, our results are much less supportive with respect to temporary shock (rank 11), countercyclical cost of finance (rank 12), menu costs (rank 13), non-price factors (rank 14) and costly information gathering (rank 15). Similar to findings from other surveys (e.g. Hall et al., 2000), we find some variation in the importance (the irrelevance) of the most important (the least important) theories across firms. Large firms and construction firms assign strongest relevance to the theory of explicit contracts, while small firms judge implicit contracts the most important obstacle to flexible prices. Constant marginal costs are particularly important for services firms, while trade firms rank thick markets (demand) first and pricing thresholds fifth, confirming that pricing thresholds are more important in retail than elsewhere. Pricing thresholds homes in at second-to-last or last in all other sectors! Also, the idea of costly information receives weak support throughout. 
Figure 8: Theories of price rigidity: mean ranks relative to mean over all theories (rating on a 4-point scale)
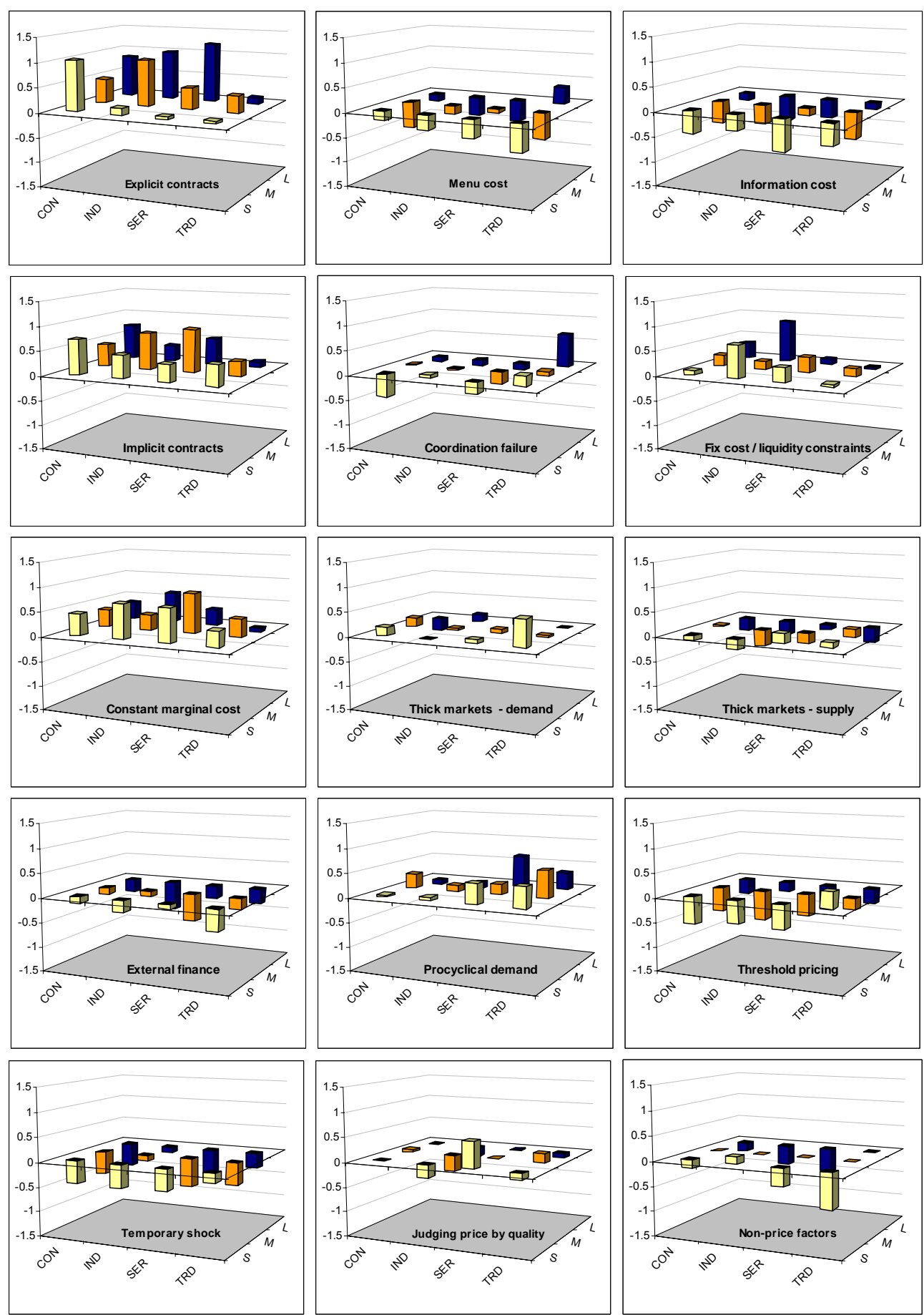

Question 20: There are numerous reasons why prices are not or only slightly changed during a certain time interval. Please indicate to what extent each of the potential reasons listed below is relevant for your company. Please choose one of the following options for each of the factors: (1) unimportant, (2) minor importance, (3) important and (4) very important. 
Figure 9: Share of firms disclosing that theory is "very important" for price rigidity
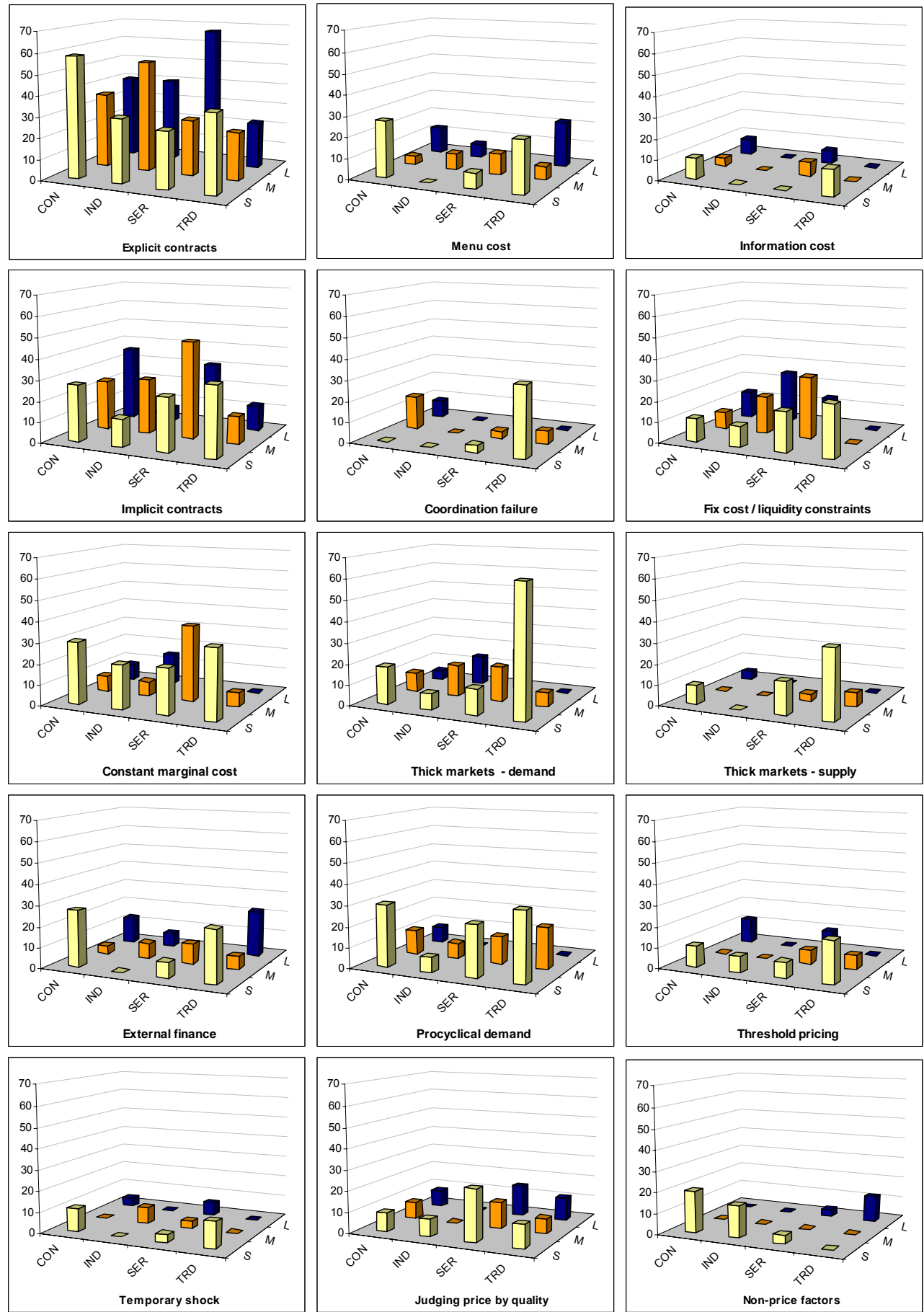
Apart from the strong average recognition, we find considerable variation in the share of firms responding that a given theory is "very important" (see Figure 9). Approximately $41 \%$ of all firms consider explicit contracts very important. We find a particularly high share for explicit contracts within the construction sector where 2 out of 3 firms consider explicit contracts as very important. At least $20 \%$ of firms recognise thick markets (demand), implicit contracts, constant marginal costs and procyclical demand as "very important" obstacles to immediate price adjustment (in decreasing order). Strikingly, the issue of coordination failure and constant marginal costs are primarily recognised as "very important" by small firms. In contrast, theories related to temporary shocks, attractive prices, countercyclical cost of finance and costly information are infrequently recognised as "very important" ( $20 \%$ of firms or less).

\section{Determinants of price changes}

Recent empirical evidence reports that price increases occur more frequently than price decreases. For the euro area countries, as well as for Luxembourg, this asymmetry is about 60:40 for unprocessed food, processed, energy and non-energy industrial goods, while it is more pronounced and closer to 80:20 for services (Dhyne et al. 2005; Lünnemann \& Mathä, 2005a,b). The reasons for this asymmetry are, however, not well explored. Peltzman (2000) provides evidence that prices respond asymmetrically to cost and demand shocks.

\subsection{Driving factors of price changes}

To assess whether there are any asymmetries related to the direction of price adjustment firms were requested to indicate the relevance of specific cost factors (such as labour costs, financial costs, other costs), changes to productivity and market conditions (such as demand and competitors' behaviour) for the decision to change the price of their main product (Question 21 and 22). Firms were asked to assess the importance of each of the potentially driving factors according to a rank scale ranging from "unimportant" (1) to "very important" (4). Figure 10 illustrates the relative importance of the respective factors for price increases and price decreases.

The results indicate very clearly that increases in labour costs are the most important factor for price increases (considered half-way between important and very important), followed by increases in other costs and wage indexation (considered important). In contrast, strengthening demand and higher prices by competitors receive the smallest average recognition as factors for price increases. The average recognition is not independent of the firm size. Productivity, capital costs, indexation and wage costs all receive higher average recognition from small firms than 
from medium-sized firms, or even more so, from large firms. Differences across sectors are moderate.

In fact, more than $60 \%$ of the firms considered an increase in labour costs as very important. The share of firms responding that a given factor is very important for price increases ranges from almost $40 \%$ in the case of wage indexation to a mere $8 \%$ for stronger demand. Below average recognition is obtained for increases in capital costs, price increases by competitors and strengthening in demand.

Figure 10: Factors of relevance - price increase relative to price decrease (rating on a 4-point scale)

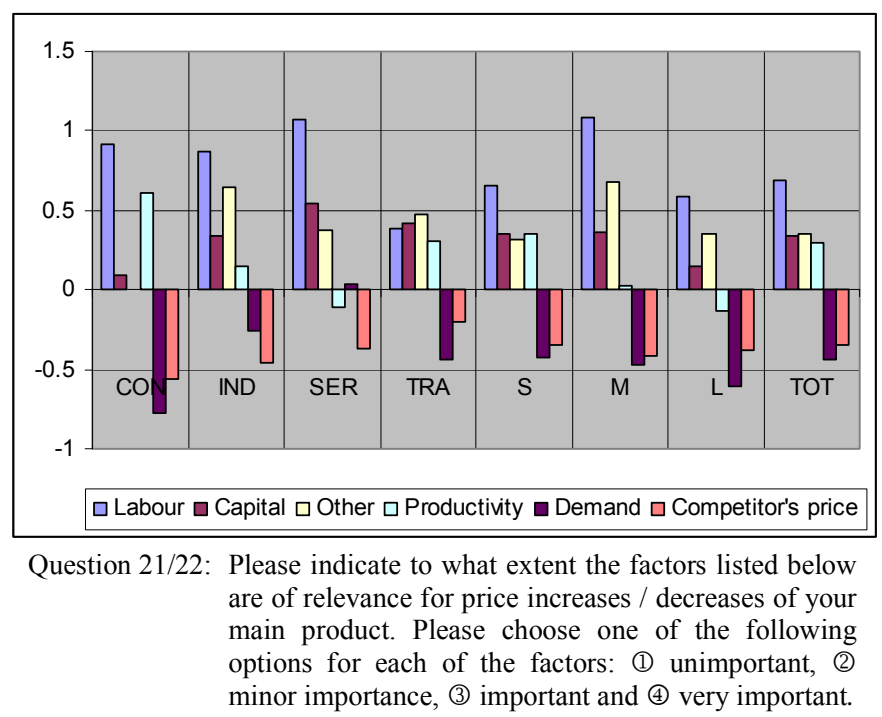

Comparing the factors of importance for price increases with those for price reductions reveals marked differences. The most important factors for price reductions are price reductions by competitors and declining wage costs, while declining capital costs and productivity increases receive the smallest average recognition (Question 22). For all factors considered except for the price of the competitors and demand fluctuations the average recognition exceeds those for price reductions.

In the case of price reductions, we find but very moderate differences across sectors and size classes with regard to the importance of factors considered. Construction firms, in particular large construction firms, consider declining demand as the most important factor for price reductions, a scenario probably not seen in Luxembourg for a decade or two. Contrary to the 
case of price increases, no single factor receives an average recognition equivalent to "important" or higher. Rather and apart from the price of the competitors and declining labour costs, all factors rank closer to "of minor importance" than to "important". Similarly, the recognition received for price reductions are well below those received for price increases. With regard to price reductions, $38 \%$ and $35 \%$ of firms consider declining labour costs and reductions in the competitor's price very important.

\subsection{Speed of price adjustments}

In assessing the degree of price stickiness it is essential not only to know the obstacles to immediate price adjustments, but also to quantify the degree of sluggishness. As the degree of sluggishness may differ in response to specific types of shock, Question 19 asks firms to estimate the speed of price adjustment in response to cost and demand shocks. In order to capture potential asymmetries in the direction of price adjustment, a distinction is made between positive and negative shocks. Firms were asked to assess the speed of adjustment according to a rank scale ranging from "less than 1 week" (1) to "the price remains unchanged" (6).

Figure 11: Asymmetries in adjustment speed

Cost up

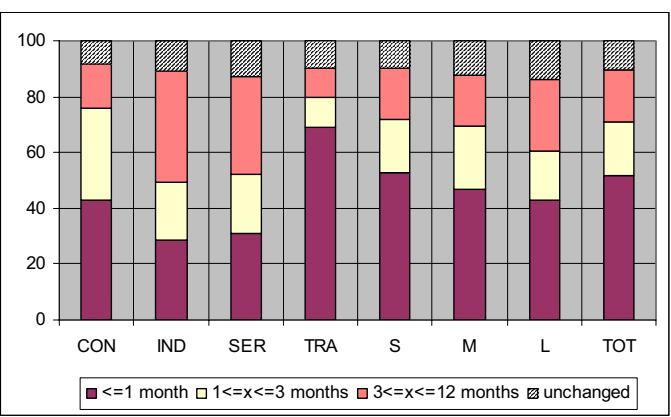

Demand up

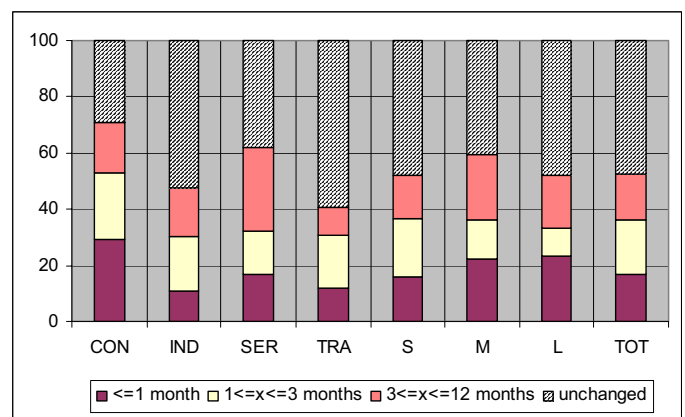

Cost down

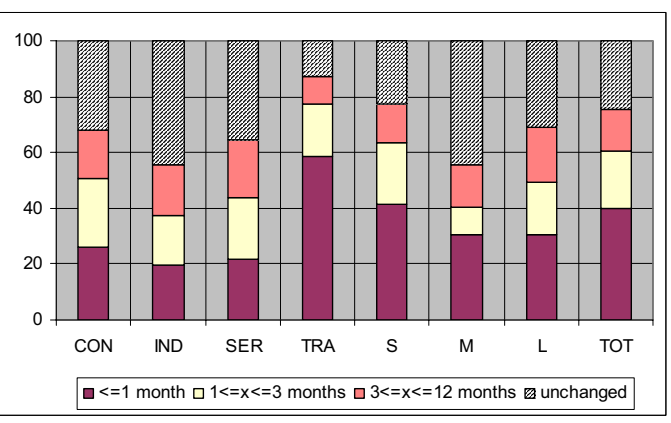

Demand down

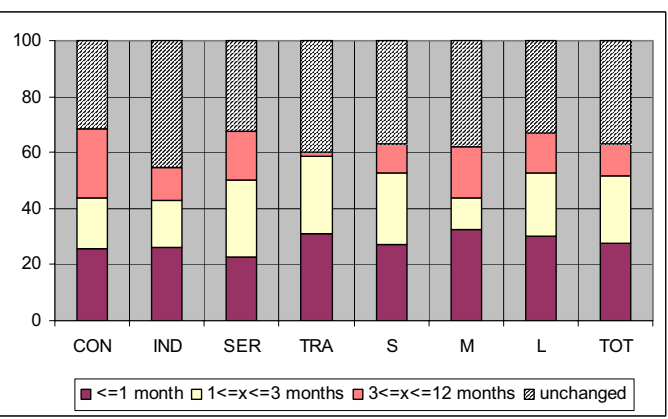

Question 19: Prices react different strongly to changes in costs and demand. If the demand / production cost of your main product increased substantially, how much time would evolve until you increased the price? If the demand / production cost of your main product decreased substantially, how much time would evolve until you decreased the price? 
Our results indeed suggest that the speed of price adjustment depends on the type and the direction of the shock. Three main results emerge: First, firms seem to raise prices relatively soon in response to an increase in production costs. Roughly $30 \%$ and $50 \%$ of firms adjust their main product's price within a single week and within a single month. In response to increasing production costs, small firms tend to adjust their prices more rapidly than large firms. In addition, we find large discrepancies across sectors. Whereas approximately $70 \%$ of trade firms adjust prices within a single month, an equally rapid price adjustment is carried out by about $30 \%$ of industrial and services firms. In fact, the median duration of price adjustment takes as long as six months among industrial firms, but less than one month for trade firms.

Second, firms adjust prices much less rapidly in response to an increase in demand. Overall, $17 \%$ of firms adjust their price within a one-month period. In contrast, for approximately $16 \%$ of those firms that eventually adjust prices, the adjustment takes place after a minimum of 3 months. The corresponding share is particularly high for services firms $(\sim 30 \%)$, but relatively small for trade firms $(<10 \%)$. In addition, following a substantial increase in demand for their main product, almost every second firm does not change their price at all. The share of firms not adjusting their prices following an increase in demand is particularly sizeable in the trade sector (almost 60\%).

Third, whereas the speed of price adjustment in response to rising costs is substantially different from that following a strengthening of demand, the speed of adjustment is much less asymmetric in the case of declining costs and shrinking demand. Overall, 37\% (25\%) of all firms do not adjust prices at all following a reduction of demand (declining costs). The share of firms not adjusting prices following a reduction of costs and in response to lower demand is particularly high for industrial firms (about $45 \%$ each). In contrast, trade firms seem to adjust prices relatively fast, with approximately $20 \%$ (29\%) of all trade firms adjusting to weakening demand (reduction in costs) within a single week. The corresponding shares for all other sectors are below $10 \%$ (construction: $1 \%$ ).

In sum, firms seem to adjust their price relatively rapidly in response to an increase in costs, but rather sluggishly in response to a reduction in costs. At the same time, firms tend to adjust their price more rapidly in response to an increase in demand rather than following a weakening in demand. 
Figure 12: Differences in adjustment speed:
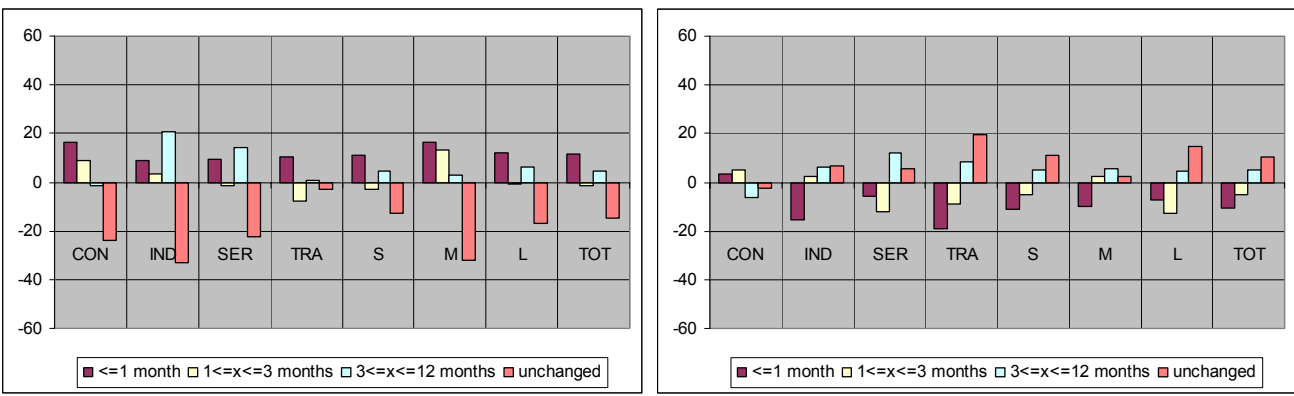

Cost up minus demand up

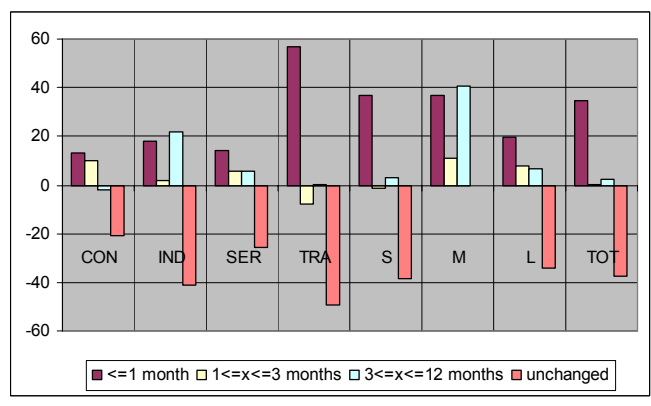

In comparison to evidence from recent firm surveys undertaken in other euro area countries, our results suggest a slightly larger fraction of firms preferring not to adjust prices at all in the response to shocks. Across all 4 scenarios analysed in the survey, the average share of firms not adjusting prices is almost $26 \%$ in Luxembourg, whereas in France, Portugal and Spain, the average share ranges from 22 to $24 \%$.

\section{Conclusions}

This paper reports the findings from a survey on the price setting behaviour of Luxembourg firms. The results show that $87 \%$ of the turnover is generated in Luxembourg whereas less than $1 \%$ of turnover is generated outside the euro area. In general, Luxembourg firms have low market share, face a relatively large number of competitors and typically maintain longstanding customer relationships. In assessing the relevance of different factors for their competitiveness, firms assigned strongest recognition to the quality of their product.

With regard to price setting practices, almost $80 \%$ of firms set prices autonomously. An almost equal share of firms is found to apply backward-looking, forward-looking and rules of thumb 
behaviour. About $20 \%$ of firms review prices in regular intervals ("time-dependence"), whereas $48 \%$ of all firms do so in response to specific events ("state-dependence"). $22 \%$ of firms generally review at specific intervals, but also in response to specific shocks. The median frequency of price reviews and of price changes is twice per year. $65 \%$ of firms apply some sort of price discrimination. Almost $70 \%$ of firms serving foreign markets charge identical prices for all markets, whereas $4 \%$ apply identical prices across euro area countries.

Overall, increases in labour costs are the most important factor for price increases, followed by increases in other costs and wage indexation. The most important factor for price reductions are price reductions by competitors and declining wage costs.

The speed of price adjustment depends on the type and the direction of the shock. Three main results emerge: First, firms seem to raise prices relatively soon in response to an increase in production costs. Approximately 50\% of firms adjust their main product's price within a single month. Second, firms seem to adjust prices much less rapidly in response to an increase in demand with almost every second firm not changing their price at all. Third, whereas the speed of price adjustment in response to rising costs is substantially different from that following a strengthening of demand, the speed of adjustment is much less asymmetric in the case of declining costs and shrinking demand.

Overall, implicit contracts are considered the most important obstacle to price adjustment. The theory of constant marginal costs comes second, while explicit contracts rank third.

\section{References}

Álvarez, L. and I. Hernando (2005): "Price setting behaviour of Spanish firms: Evidence from survey data", Banco de España, ECB Working Paper No. 538.

Apel, M., R. Friberg and K. Hallsten (2005): "Micro foundations of macroeconomic price adjustment: survey evidence from Swedish firms", in Journal of Money, Credit and Banking, Vol. 37, No. 2, pp. 313-338.

Asplund, M. and R. Friberg (1998): "Links between competition and inflation", in Sveriges Riksbank Quarterly Review, Vol. 3, pp. 50-73.

Aucremanne, L. and M. Druant (2005): "Price-setting behaviour in Belgium: What can be learned from an ad hoc survey?", ECB Working Paper No. 448.

Blinder, A.S., E. Canetti, D.E. Lebow and J.B. Rudd (1998): Asking about prices: A new approach to understanding price stickiness, Russell Sage Foundation, New York.

Carlton, D.W. (1986): "The rigidity of prices", in American Economic Review, Vol. 76, No. 4, pp. 637-658. 
Dhyne, E., L. Álvarez, H. Le Bihan, G. Veronese, D. Dias, J. Hoffman, N. Jonker, P. Lünnemann, F. Rumler and J. Vulminen (2005): "Price setting in the euro area: some stylised facts from individual consumer price data", ECB Working Paper No. 524.

Dornbusch, R. (1987): "Exchange rates and prices", in American Economic Review, Vol. 77, No.1, pp. 93-106.

Fabiani, S., M. Druant, I. Hernando, C. Kwapil, B. Landau, C. Loupias, T. Mathä, R. Sabbatini, H. Stahl, A. Stokman (2005): "The pricing behaviour of firms in the Euro Area: New survey evidence", ECB Working Paper No. 535.

Fabiani, S., A. Gattulli and R. Sabbatini (2004): "The pricing behaviour of Italian firms: New survey evidence on price stickiness”, ECB Working Paper No. 333.

Hall, S., M. Walsh and A. Yates (1996): “How do UK companies set prices?", Bank of England Quarterly Bulletin, Vol. 6, No. 2, pp. 1-13.

Hall, S., M. Walsh and A. Yates (2000): “Are UK companies' prices sticky?”, in Oxford Economic Papers, Vol. 52, pp. 425-46.

Hoeberichts, M. and A. Stokman (2006): "Pricing behaviour of Dutch companies: Main results from a survey”, ECB Working Paper No. 607.

Kwapil, C., J. Baumgartner and J. Scharler (2005): "The price-setting behaviour of Austrian firms: Some survey evidence”, ECB Working Paper No. 464.

Loupias, C. and R. Ricart (2004): "Price setting in France: New evidence from survey data", ECB Working Paper No. 448.

Lünnemann, P. and T.Y. Mathä (2005a): "Consumer price behaviour in Luxembourg: Evidence from micro CPI data”, Banque centrale du Luxembourg Cahier d'Études No. 17.

Lünnemann, P. and T.Y. Mathä (2005b): "Nominal rigidities and inflation persistence in Luxembourg: A comparison with EU15 member countries with particular focus on services and regulated prices", Banque centrale du Luxembourg Cahier d'Études No. 14.

Martins, F. (2005): "The price setting behaviour of Portuguese firms: Evidence from survey data", ECB Working Paper No. 562.

Okun, A. (1981): Prices and quantities: A macroeconomic analysis, (The Brookings Institution: Washington D.C.).

Peltzman, S. (2000): "Prices rise faster than they fall", in Journal of Political Economy, Vol. 108, No. 3, pp. 466-502.

Rotemberg, J. and G. Saloner (1987): “The relative rigidity of monopoly pricing”, in American Economic Review. Vol. 77, pp. 917-926.

Stahl, H. (2005): "Price setting in German manufacturing: New evidence from survey data", ECB Working Paper No. 561. 


\section{Appendix}

WC( Please return the completed questionnaire by 8 October 2004
SUR VEY ON PRICING BEHAVIOUR
You may use the enclosed free of charge self-addressed envelope or our fax number +35247744920.
$\begin{aligned} & \text { Remark: The notion "price" refers to the price actually charged, even if this price deviates from the pricing list. If different } \\ & \text { prices are charged for different types of customers, please refer to the most common customer type in your subsequent }\end{aligned}$

answers.

Name of Company:

Name and position of person completing the survey:

Phone number:

E-mail :

General Information

1. Total turnover of your company in the last fiscal year (excl. VAT):

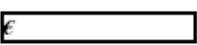

2. What share of the total turnover is generated in the following regions.

2.1. Luxembourg

2.2. In the euro area (except Luxembourg)

2.3. Outside the euro area

Total

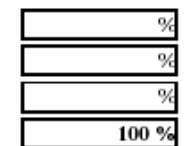

3. Number of employees in your company

4. What is your main product, i.e. the product that generates the highest turnover?

For companies in the services sector, the main product is to mean the main activity.

5. What percentage share of the turnover does your main product account for?

6. Which country reflects in terms of the turnover of your main product the most important market? (Please fick one answer only)

6.1. Luxembourg .

6.2. A different country in the euro area

6.3. A country outside the euro area

In the following, your answers should exclusively refer to the relevant Luxembourg market of your main product (Q4).

For companies in the services sector, the main product is to mean the main activity.

If your company is not present on the Luxembourg market, you have already answered all relevant questions.

Please use the self-addressed envelope to return the questionnaire. Thank you very much for your cooperation!

7. How many competitors (national and international) do you encounter for your main product on the Luxembourg market?

(Please tick one answer only)

7.1. None

7.2. Less than 5

7.3. Between 5 and 10

7.4. More than 10

7.5. I don't know 


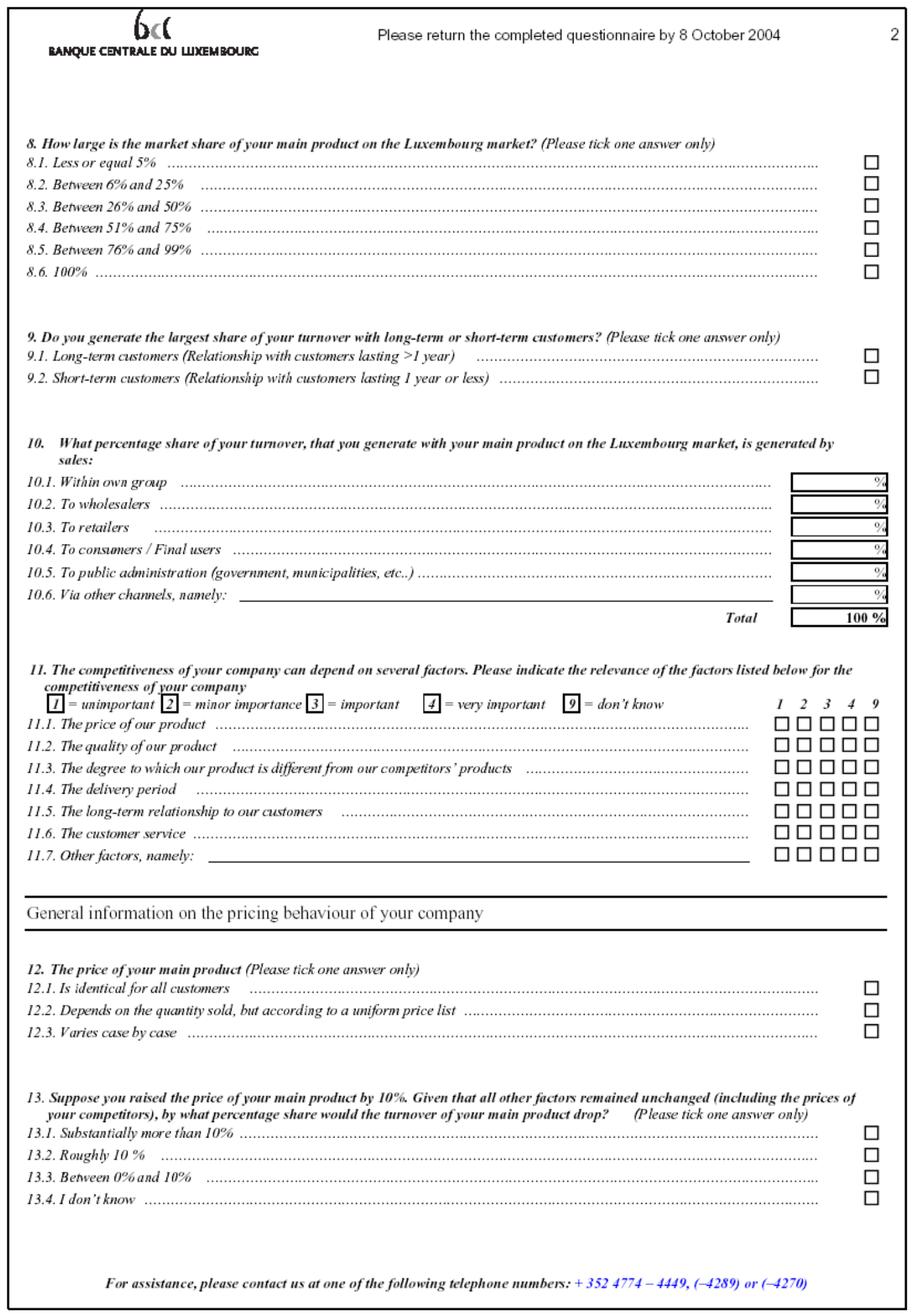




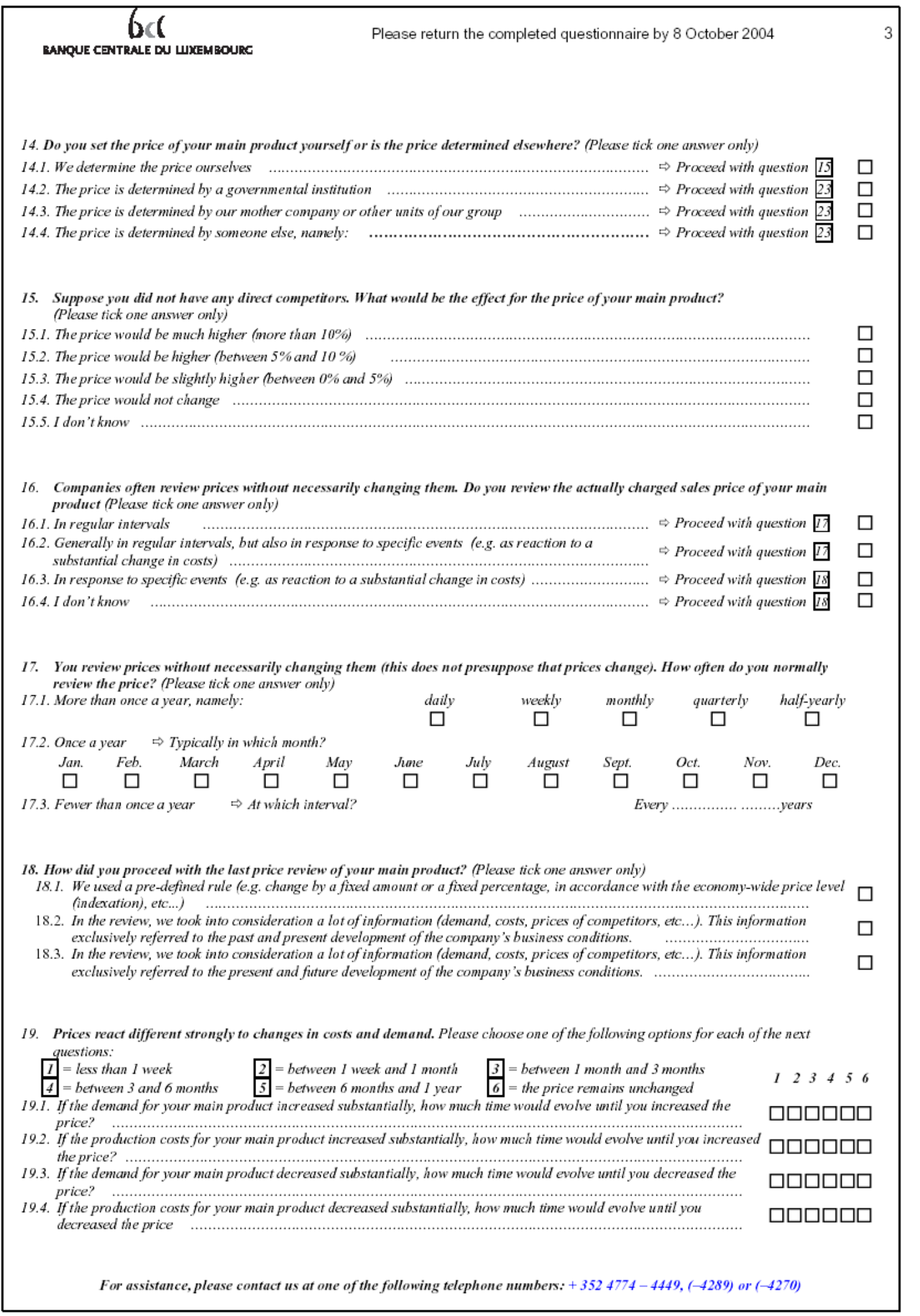




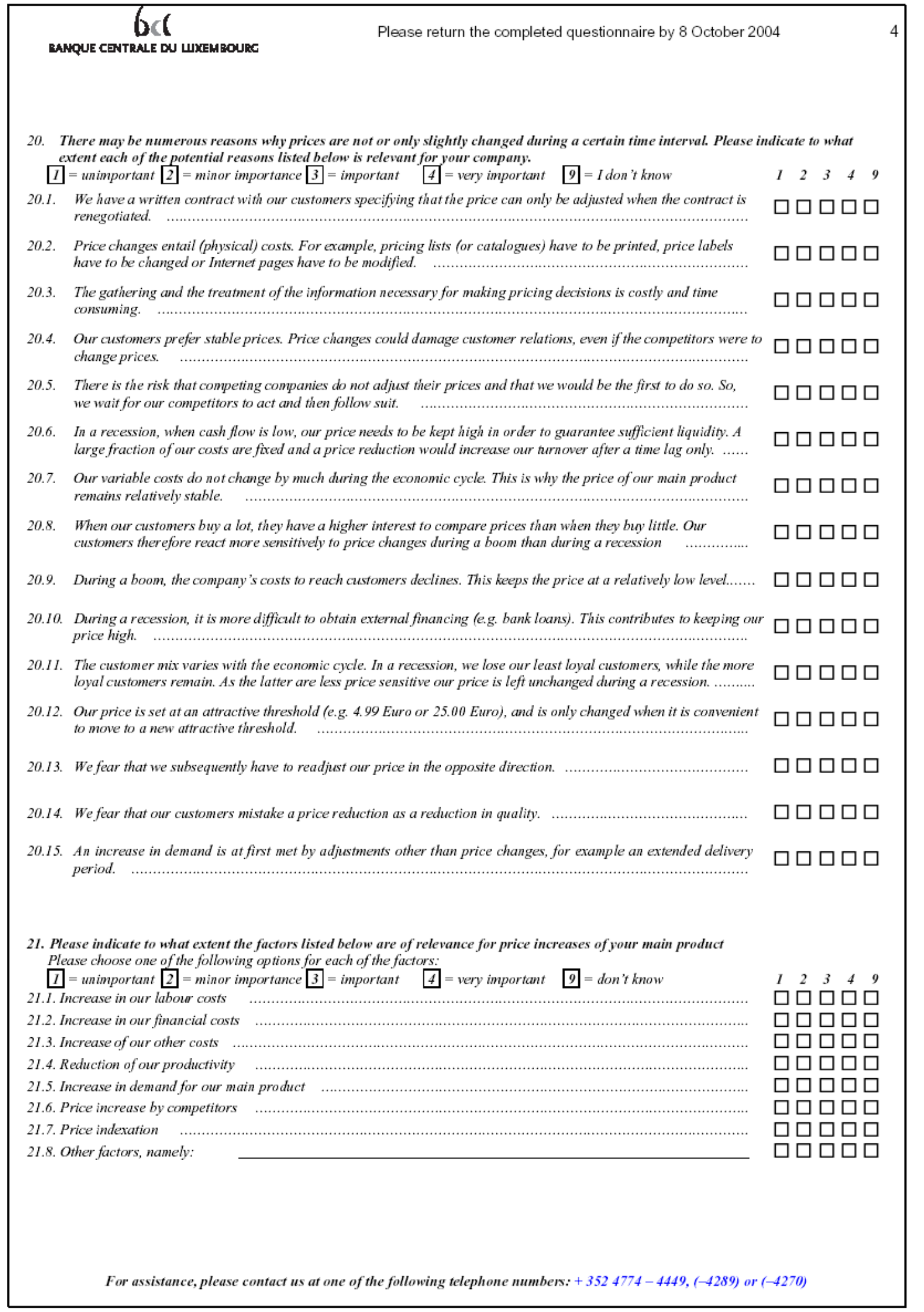




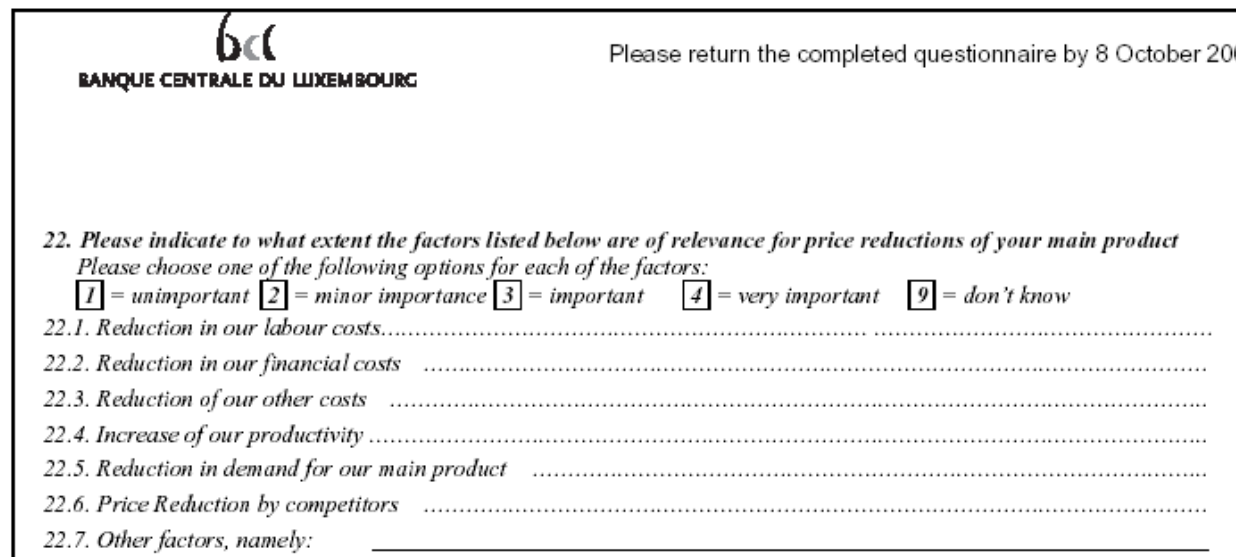

$\begin{array}{lllll}1 & 2 & 3 & 4 & 9\end{array}$ 맘ำ 맘ำ व्वप्र ㅁप맘 무맘 ㅁपㅁำ 마맘

23. At which interval do you change the price of your main product (please also consider possible discounts, but not end-of season sales or similar) (Please tick one answer only)

23.L. More than once a year, namely:

daily weekly monthly quarterly half-yearly

23.2. Once a year $\Rightarrow$ Typically in which month?

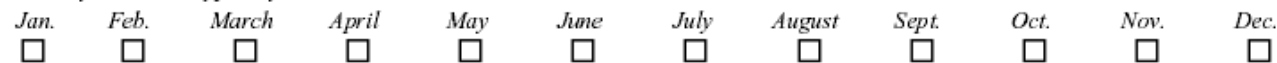

23.3. Fewer than once a year $\Rightarrow$ At which interval? $\quad$ Every ........................years

Pricing Behaviour outside the Luxembourg Market

(To be completed by companies only that are present on foreign markets (see question 2)

24. Companies may charge different prices on different markets: Which of the following statements is true for your company? (Please tick one answer only)

24.I. The price - expressed in euro - is identical in all countries ........................................... $\Rightarrow$ Proceed with question 20

24.2. The price - expressed in euro - is identical in all countries of the euro area but not identical for countries outside the euro area

$\Rightarrow$ Proceed with question 28

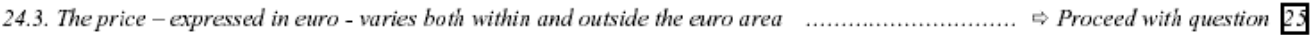

25. Please indicate to what extent the following factors are relevant for the pricing behaviour of a product

Please choose one of the following options for each of the factors:

$1]=$ unimportant $[2=$ minor importance $3=$ important $\quad 4=$ very important $\quad 9=$ don't know

25.2. Tax system (e.g. VAT)

25.3. Transport costs

25.4. Structural conditions on the respective market (e.g. preferences, living standard,...)

25.5. Cyclical changes in demand

25.6. Price of competitor (s)

25.7. Level of regulation ......

25.8. Other factors, namely:

26. With regard to your main product, is competition on the foreign market fiercer than on the Luxembourg market? (Please tick one answer only)

26.1. Yes.

26.2. No

26.3. I don't know

Thank you very much for your cooperation! 


\section{European Central Bank Working Paper Series}

For a complete list of Working Papers published by the ECB, please visit the ECB's website (http://www.ecb.int)

585 "Are specific skills an obstacle to labor market adjustment? Theory and an application to the EU enlargement” by A. Lamo, J. Messina and E. Wasmer, February 2006.

586 "A method to generate structural impulse-responses for measuring the effects of shocks in structural macro models" by A. Beyer and R. E. A. Farmer, February 2006.

587 "Determinants of business cycle synchronisation across euro area countries" by U. Böwer and C. Guillemineau, February 2006.

588 "Rational inattention, inflation developments and perceptions after the euro cash changeover" by M. Ehrmann, February 2006.

589 "Forecasting economic aggregates by disaggregates" by D. F. Hendry and K. Hubrich, February 2006.

590 "The pecking order of cross-border investment" by C. Daude and M. Fratzscher, February 2006.

591 "Cointegration in panel data with breaks and cross-section dependence" by A. Banerjee and J. L. Carrion-i-Silvestre, February 2006.

592 "Non-linear dynamics in the euro area demand for MI" by A. Calza and A. Zaghini, February 2006.

593 “Robustifying learnability” by R. J. Tetlow and P. von zur Muehlen, February 2006.

594 “The euro's trade effects” by R. Baldwin, comments by J. A. Frankel and J. Melitz, March 2006.

595 "Trends and cycles in the euro area: how much heterogeneity and should we worry about it?" by D. Giannone and L. Reichlin, comments by B. E. Sørensen and M. McCarthy, March 2006.

596 "The effects of EMU on structural reforms in labour and product markets" by R. Duval and J. Elmeskov, comments by S. Nickell and J. F. Jimeno, March 2006.

597 "Price setting and inflation persistence: did EMU matter?" by I. Angeloni, L. Aucremanne, M. Ciccarelli, comments by W. T. Dickens and T. Yates, March 2006.

598 "The impact of the euro on financial markets" by L. Cappiello, P. Hördahl, A. Kadareja and S. Manganelli, comments by X. Vives and B. Gerard, March 2006.

599 "What effects is EMU having on the euro area and its Member Countries? An overview" by F. P. Mongelli and J. L. Vega, March 2006.

600 “A speed limit monetary policy rule for the euro area” by L. Stracca, April 2006.

601 "Excess burden and the cost of inefficiency in public services provision" by A. Afonso and V. Gaspar, April 2006. 
602 "Job flow dynamics and firing restrictions: evidence from Europe" by J. Messina and G. Vallanti, April 2006.

603 “Estimating multi-country VAR models" by F. Canova and M. Ciccarelli, April 2006.

604 “A dynamic model of settlement” by T. Koeppl, C. Monnet and T. Temzelides, April 2006.

605 “(Un)Predictability and macroeconomic stability” by A. D'Agostino, D. Giannone and P. Surico, April 2006.

606 "Measuring the importance of the uniform nonsynchronization hypothesis" by D. A. Dias, C. Robalo Marques and J. M. C. Santos Silva, April 2006.

607 "Price setting behaviour in the Netherlands: results of a survey" by M. Hoeberichts and A. Stokman, April 2006.

608 "How does information affect the comovement between interest rates and exchange rates?" by M. Sánchez, April 2006.

609 "The elusive welfare economics of price stability as a monetary policy objective: why New Keynesian central bankers should validate core inflation” by W. H. Buiter, April 2006.

610 "Real-time model uncertainty in the United States: the Fed from 1996-2003" by R. J. Tetlow and B. Ironside, April 2006.

6II "Monetary policy, determinacy, and learnability in the open economy" by J. Bullard and E. Schaling, April 2006.

612 "Optimal fiscal and monetary policy in a medium-scale macroeconomic model" by S. Schmitt-Grohé and M. Uribe, April 2006.

613 "Welfare-based monetary policy rules in an estimated DSGE model of the US economy" by M. Juillard, P. Karam, D. Laxton and P. Pesenti, April 2006.

614 "Expenditure switching vs. real exchange rate stabilization: competing objectives for exchange rate policy" by M. B. Devereux and C. Engel, April 2006.

615 "Quantitative goals for monetary policy” by A. Fatás, I. Mihov and A. K. Rose, April 2006.

616 "Global financial transmission of monetary policy shocks" by M. Ehrmann and M. Fratzscher, April 2006.

617 "New survey evidence on the pricing behaviour of Luxembourg firms" by P. Lünnemann and T. Y. Mathä, May 2006. 
